Article

\title{
Surface Characterization and Copper Release of a-C:H:Cu Coatings for Medical Applications
}

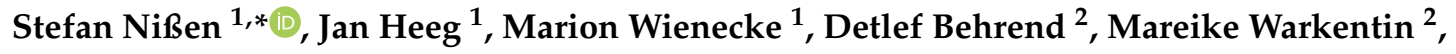 \\ Krzysztof Rokosz ${ }^{3}$, Sofia Gaiaschi ${ }^{4}$ and Patrick Chapon ${ }^{4}$ \\ 1 Institute of Surface and Thin Film Technology, Hochschule Wismar, Philipp-Mueller-Strasse 14, \\ 23966 Wismar, Germany; jan.heeg@hs-wismar.de (J.H.); marion.wienecke@hs-wismar.de (M.W.) \\ 2 Department of Material Science and Medical Engineering, Faculty of Mechanical Engineering and Marine \\ Technology, University of Rostock, 18051 Rostock, Germany; detlef.behrend@uni-rostock.de (D.B.); \\ mareike.warkentin@uni-rostock.de (M.W.) \\ 3 Division of BioEngineering and Surface Electrochemistry, Department of Engineering and Informatics \\ Systems, Koszalin University of Technology, Racławicka 15-17, PL 75-620 Koszalin, Poland; \\ rokosz@tu.koszalin.pl \\ 4 HORIBA FRANCE S.A.S, Avenue de la Vauve-Passage Jobin Yvon, CS 45002-91120 Palaiseau, France; \\ sofia.gaiaschi@horiba.com (S.G.); patrick.chapon@horiba.com (P.C.) \\ * Correspondence: stefan.nissen@hs-wismar.de; Tel.: +49-3841-753-7179
}

Received: 20 November 2018; Accepted: 6 February 2019; Published: 14 February 2019

check for updates

\begin{abstract}
This paper focuses on the surface properties of a-C:H:Cu composite coatings for medical devices and how the release of $\mathrm{Cu}^{2+}$ ions from such coatings can be controlled. The released $\mathrm{Cu}$ ions have the potential to act as a bactericidal agent and inhibit bacterial colonization. A PVD-PECVD hybrid process was used to deposit a-C:H:Cu composite coatings onto Ti6Al4V substrates. We examine the layer surface properties using atomic force microscopy and static contact angle measurements. An increasing surface roughness and increasing contact angle of Ringer's solution was measured with increasing copper mole fraction $\left(X_{\mathrm{Cu}}\right)$ in the coatings. The contact angle decreased when a supplementary bias voltage of $-50 \mathrm{~V}$ was used during the a-C:H:Cu deposition. These findings are in line with earlier published results regarding these types of coatings. The release of $\mathrm{Cu}^{2+}$ ions from a-C:H:Cu coatings in Ringer's solution was measured by anodic stripping voltammetry. Different layer structures were examined to control the time-resolved $\mathrm{Cu}$ release. It was found that the $\mathrm{Cu}$ release depends on the overall $\mathrm{X}_{\mathrm{Cu}}$ in the a-C:H:Cu coatings and that an additional a-C:H barrier layer on top of the a-C:H:Cu layer effectively delays the release of $\mathrm{Cu}$ ions.
\end{abstract}

Keywords: DLC; copper filled; ion release; medical; coating; amorphous carbon

\section{Introduction}

Regardless of aseptic surgical conditions and perioperative antibiotic prophylaxis, aseptic infection and loosening of implants are still serious potential complications in orthopedic surgery. Early infections can occur up to 90 days after operation and are usually acquired during the surgical procedure or as a result of implant-associated infections (peri-implantitis) [1]. Infection rates range between $0.3 \%$ and $1.7 \%$ after primary total hip replacement [2-4] and approximately $0.8 \%$ to $1.9 \%$ after primary total knee replacement $[2,5,6]$. When focusing on screw implants in orthodontics, the average success rate of dental mini- and microimplants is $84-88 \%$ according to various meta-analyses of clinical trials [7-9]. To a significant extent (7\% [10]) there is a loss of primary stability from peri-implant infections due to an exposed germination site at the entry to the gingiva. This leads to a reduction of the success rate by 10.9 [11] and 32.2 [12] percentage points. According to a meta-analysis of 15 studies, 
the mean prevalence of peri-implantitis is $22 \%$ (CI: 14-30\%) [13]. Such implants are often made out of titanium alloys like Ti6Al4V.

The treatment of implant-related infections has become more and more difficult, since the excessive treatment with antibiotics has led to the formation of multi-resistant germs through spontaneous mutation or by DNA transfer $[13,14]$. This is one of the greatest current threats in the clinical practice.

To prevent these implant-related infections, a number of implant surface modifications that inhibit bacterial colonization through the release of antibacterial substances, like coupling of antibiotics [15-20], have been developed. Since ancient times, silver and copper have been known as an effective antimicrobial agent, with a large spectrum against multiple drug-resistant bacteria combined with a reduced cytotoxicity [21-24]. Therefore, titanium surfaces were already modified by adding metal ions of $\mathrm{Zn}, \mathrm{Ag}$ and $\mathrm{Cu}[20,23,25,26]$.

When using such surface modification for implant devices, the biocompatibility and, particularly, the cytotoxicity of the surface must be considered. The release of $\mathrm{Ag}$ or $\mathrm{Cu}$ ions creates an antibacterial effect of the coating; however, silver ions show higher dose-related cytotoxicity when compared to copper ions [27], which can have several detrimental effects [28]. Moreover, while silver tends to accumulate in the human body and increases the silver serum levels [29] copper is a metabolizable element [30]. Therefore, the two opposing objectives of antibacterial activity and biocompatibility have to be well-balanced when developing coatings for implant devices. To do so, antibacterial effects have to be based on a time-controlled release of the specific antibacterial substances.

Furthermore, the success of an antibacterial coating, like other release-based systems, depends on the ability to control and tune the time frame and kinetics of the release of metal ions from the coating. A critical step for controlling ion release from metal filled coatings depends on the oxidization mechanism in which the metal is transformed into reactive and soluble metal ions. To this effect, part of the research has been focused on various approaches to control and enhance the oxidative dissolution [31]. The surface-dependent factors like distribution, size, concentration, shape or charge of the antibacterial substance, the porosity and roughness of the coating's matrix as well as the overall micro- and nanostructure of the coating, are known to influence the ion release kinetics [32]. In this regard, a fine particle size and the incorporation of oxygen species can improve the Ag ions dissolution rate [33]. Additionally, nano-structuring the surface is also a valuable method to control antibacterial activity due to the high surface to volume ratio, which increases the surface reactivity [34].

In order to better control the ion release, the embedding of metal ions or nanoparticles in different organic or inorganic matrixes like PMMA [35,36], PAA/PAH [28], PVA [37], Si-based sol-gel [38] and gelatin fibers [39] has been investigated. Furthermore, silver was embedded in plasma-based coatings like oxygen-containing [40] or nitrogen-containing [41] plasma polymer films. The use of metal containing amorphous carbon coatings like $\mathrm{Cu} / \mathrm{DLC}$ or Ag/DLC is also under investigation. Therefore, metal nanoparticles are embedded into the a-C:H matrix. Modifying DLC with different metallic elements such as $\mathrm{Cr}[42,43]$, Ti [42,44], W [45,46] and Mo [46] can lead to new functions of the DLC thin films. Adding non-carbide-forming elements like Ag [47,48], Cu [49], Al [50] and Ni [50] into the DLC matrix can reduce residual stress [43,45,47-50] and improve electric conductivity [44,51]. Furthermore, copper- or silver-containing DLC thin films can show a significant antibacterial effect [52-56]. These composite coatings have been deposited by Arc evaporation with metal cathodes [57], magnetron sputtering [51], ion plating/sputtering [58], pulsed laser deposition [21,59-61], laser ablation [62, 63], plasma-immersion ion implantation [64], ion deposition [54], plasma-enhanced chemical vapor deposition (PECVD) [47] and variations thereof. Their use for antibacterial surface modification of biomedical implants and environmental surfaces by the release of antibacterial $\mathrm{Ag}$ and $\mathrm{Cu}$ ions has been widely studied $[20,54,56,65-67]$.

The release of copper ions from these thin composite films is influenced by the film thickness, substrate roughness and crystallographic structure of the deposited film [68]. Furthermore, the copper release from a surface depends on the exposed area used in the application and on the availability of 
the deposited copper. A sufficient (about $5 \mathrm{mmol} / \mathrm{L}$ ) and enduring release of copper ions for several days is required to inhibit bacterial proliferation and subsequently to kill all bacteria and, therefore, prevent the formation of a more resistant biofilm [69-71]. To ensure a long-lasting release, it has been proposed to use additional top layers that act as a diffusion barrier [41,72].

This paper reports on the surface properties like roughness and wettability and the time-resolved release kinetics of copper ions $\left(\mathrm{Cu}^{2+}\right)$ from a-C:H:Cu coatings, which were deposited onto Ti6Al4V substrates. A hydrophobic a-C:H barrier layer should be able to reduce the initial burst release and sustain a sufficient release over several days.

\section{Materials and Methods}

\subsection{Deposition Methods}

Coated cylindrical titanium alloy Ti6Al4V specimens (Ti grade $23 \mathrm{ELI}, \varnothing=11 \mathrm{~mm}$ ) with a thickness of $2 \mathrm{~mm}$ were used for the release measurements (Figure 1a). Here only a short summary of the deposition steps is given, as the detailed deposition processes are already described in another paper [73]. The whole process consisted of three deposition steps (Figure 1b). At first, a chemical gradient $\mathrm{Ti} / \mathrm{Ti}_{x} \mathrm{C}_{y} / \mathrm{a}-\mathrm{C}: \mathrm{H}: \mathrm{Ti}$ bonding layer system was deposited by DC magnetron sputtering of a Ti target (99.99\% purity; $\varnothing=50 \mathrm{~mm}$ ) in $\mathrm{Ar}$ and $\mathrm{Ar} / \mathrm{C}_{2} \mathrm{H}_{2}$ atmosphere (99.9999\%/99.5\% purity). The deposition time of $15 \mathrm{~min}$ with a deposition rate of $1.2 \mathrm{~nm} / \mathrm{s}$ led to a Ti/ $\mathrm{Ti}_{x} \mathrm{C}_{y} / \mathrm{a}-\mathrm{C}: \mathrm{H}: \mathrm{Ti}$ layer system thickness of $1 \mu \mathrm{m}$. Afterwards, a $400 \mathrm{~nm}$ thick a-C:H diffusion barrier layer was deposited in a radio frequency magnetron plasma-enhanced chemical vapor deposition (RF-magPECVD) process at a pressure of $0.7 \mathrm{~Pa}$ for a duration of $8 \mathrm{~min}(0.8 \mathrm{~nm} / \mathrm{s})$. The structure of the chemical gradient $\mathrm{Ti} / \mathrm{Ti}_{x} \mathrm{C}_{y} / \mathrm{a}-\mathrm{C}: \mathrm{H}: \mathrm{Ti} / \mathrm{a}-\mathrm{C}: \mathrm{H}$ layer system is shown in Figure 3 . The $\mathrm{Ti}_{x} \mathrm{C}_{y}$ has a columnar structure which changes to amorphous carbon at the surface.

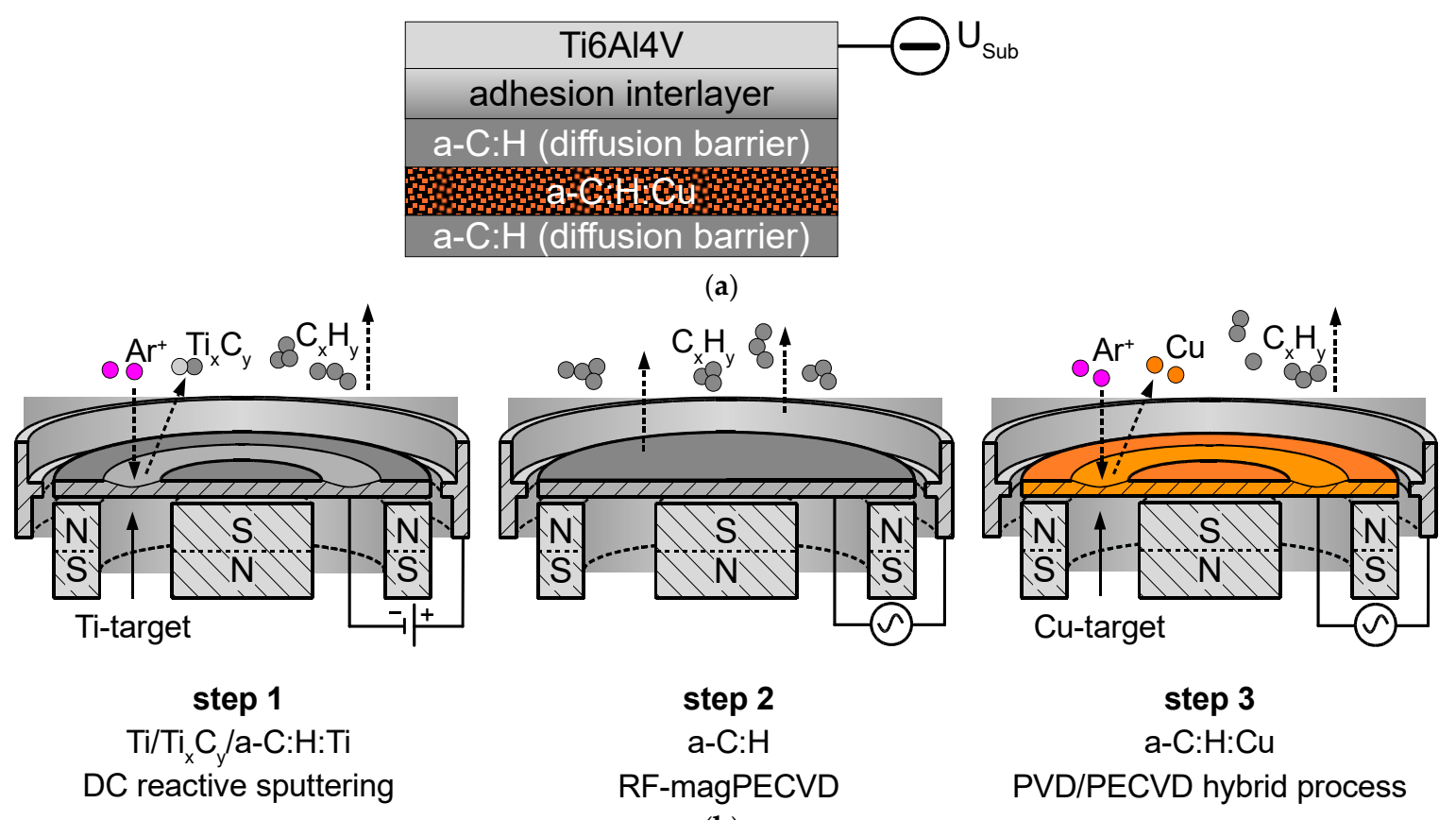

(b)

Figure 1. Schematic layer system (a) and illustration of utilized process steps (b).

Next, the top a-C:H:Cu layer was deposited in an $\mathrm{Ar} / \mathrm{C}_{2} \mathrm{H}_{2}$ atmosphere with a $\mathrm{Cu}$ target $(99.98 \%$ purity; $\varnothing=50 \mathrm{~mm}$ ) by using a RF-PVD/PECVD hybrid process. Additionally, a supplementary bias voltage of $-50 \mathrm{~V}$ was applied at the substrate holder by a DC power supply, which was deliberately kept low $(<-100 \mathrm{~V})$ because a higher electric potential leads to significant resputtering of the coatings 
by $\mathrm{Ar}$ ions. The process pressure during a-C:H:Cu deposition was kept constant at $1 \mathrm{~Pa}$ for all coating experiments. $\mathrm{X}_{\mathrm{Cu}}$ was varied by using different $\mathrm{C}_{2} \mathrm{H}_{2}$ partial pressures (8.3-40 MPa) during deposition. The deposition time was 30 min leading to an a-C:H:Cu layer thickness in the range of $710-1750 \mathrm{~nm}$. It is worth noting that, despite similar deposition times, different coating thicknesses were obtained, mainly as a result of differences in the sputtering rate of the $\mathrm{Cu}$ target with the variation of the $\mathrm{C}_{2} \mathrm{H}_{2}$ partial pressure, in order to influence $X_{\mathrm{Cu}}$.

\subsection{Chemical and Structural Characterisation}

The layer's structural properties were examined using scanning electron microscope SEM (Zeiss Auriga Compact, Oberkochen, Germany) with an accelerating voltage of $20 \mathrm{kV}$. Layer cross sections were examined to determine the layer thickness by SEM.

The overall elemental composition of the deposited a-C:H:Cu layers was evaluated by the energy dispersive X-ray spectroscopy (EDX) method. Since parts of the (titanium carbide) TiC-based interlayer were also probed by EDX, there was a risk that the $C$ content was slightly overestimated for the examined a-C:H:Cu layers. The accelerating voltage was $20 \mathrm{kV}$ for all EDX measurements. The obtained spectra were analyzed using the eZAF routine, provided within the EDAX TEAM software (V 4.2), and results were calculated as molar fraction $\left(X_{\mathrm{i}}\right)$ of species i (numerically identical with at \%).

The elemental depth profiles of the coatings were obtained by glow discharge optical emission spectroscopy (GDOES) [74] using a Horiba Scientific GD Profiler 2 instrument (HORIBA Scientific, Palaiseau, France). A pulsed radio frequency (RF) source (700 Pa, $40 \mathrm{~W}, 3000 \mathrm{~Hz})$, with anode diameter equal to $4 \mathrm{~mm}$ (analyzed surface area equal to $12.56 \mathrm{~mm}^{2}$ ), was used.

\subsection{Surface Characterization}

Atomic force microscope (AFM) measurements (intermittent contact mode, Air) of surface roughness were conducted with a NanoWizard AFM (JPK instruments AG, 2004, Berlin, Germany). The measurement area was $10 \mu \mathrm{m} \times 10 \mu \mathrm{m}$ and the tip velocity $17.96 \mu \mathrm{m} / \mathrm{s}$. Measurements were evaluated and visualized using JPK Data Processing software (V 4.3.55). The obtained mean roughness $\left(R_{\mathrm{a}}\right)$ and mean square roughness $\left(R_{\mathrm{q}}\right)$ were calculated from a histogram of pixel values.

To examine the surface's wetting behaviour, static contact angle measurements where taken using a DSA 100 (Krüss, Hamburg, Germany). The biomedical application required the use of an artificial serum, Ringer's solution, as the contact medium. Statistical significance between measured samples was calculated using two sample t-tests for unequal sample size and unequal variance $(\alpha=0.05)$.

\subsection{Release of $\mathrm{Cu}^{2+}$ Ions}

Quantitative measurements of dissolved copper ions $\left(\mathrm{Cu}^{2+}\right)$ in Ringer's solution (B. Braun, Melsungen, Germany) were performed using an electrochemical detection method called square-wave anodic stripping voltammetry. The ion species was determined by the position of the peak potential in the I/V-curve $\left(-0.3--0.2 \mathrm{~V}\right.$ for $\left.\mathrm{Cu}^{2+}\right)$ [75]. The standard addition method using standard solutions with different $\mathrm{Cu}$ concentration (Ringer's solution with copper(II) sulfate) was used.

Measurements were conducted using screen-printed electrodes IS-HM1 (ItalSens) and EmStat potentiostat (PalmSens BV, Houten, The Netherlands). To measure the $\mathrm{Cu}^{2+}$ release from the material surface, coated Ti6Al4V specimens were immersed in $10 \mathrm{~mL}$ of Ringer's solution with a constant temperature of $37^{\circ} \mathrm{C}$. For this purpose, a peristaltic pump was connected to the measuring cell (Figure 2), which kept the release medium in a constant flow. After various time points, the samples were analyzed using a standard protocol. The release medium was changed every hour or day, depending on measurement conditions. 


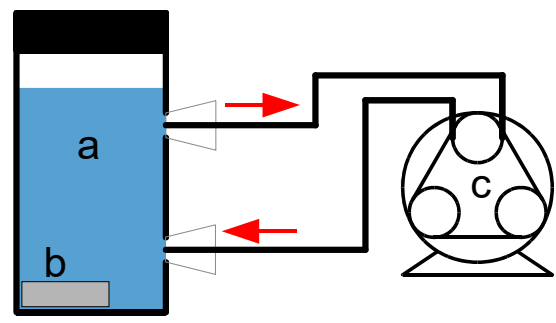

Figure 2. Measuring cell with Ringer's solution (a), a-C:H:Cu specimen (b) and peristaltic pump (c).

\section{Results and Discussion}

\subsection{Surface Topography}

Besides the coated samples, an uncoated but polished Ti6Al4V sample with $R_{\mathrm{q}}=1.94 \mathrm{~nm}$ was examined for reference. When applying the first layer system with its columnar grown $\mathrm{Ti} / \mathrm{Ti}_{x} \mathrm{C}_{y} / \mathrm{a}-\mathrm{C}: \mathrm{H}$ :Ti bonding layer (see Figure 3) the surface roughness increased to $R_{\mathrm{q}}=3.61 \mathrm{~nm}$.

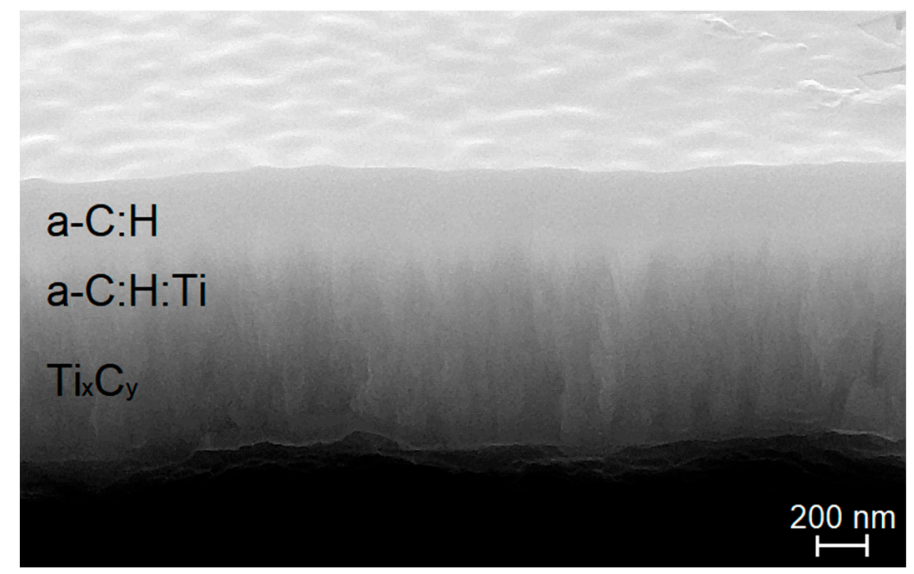

Figure 3. SEM image of cross section of the underlying $\mathrm{Ti} / \mathrm{Ti}_{x} \mathrm{C}_{y} / \mathrm{a}-\mathrm{C}: \mathrm{H}: \mathrm{Ti} / \mathrm{a}-\mathrm{C}: \mathrm{H}$ layer system (perspective view).

The adding of $\mathrm{Cu}$ to the a-C:H matrix led to a further increase in roughness, depending on the overall $\mathrm{Cu}$ content of the a-C:H:Cu coating (see Table 1 ). This can been related to the increase in the size of $\mathrm{Cu}$ clusters in the a-C:H matrix. It can be noted that the particle diameter on the surface, measured with AFM, ranged between 100 and $400 \mathrm{~nm}$ (Figure 4), while scanning TEM (STEM) examinations in previous work [73] showed $\mathrm{Cu}$ particle size of 1.5-22 $\mathrm{nm}$. The relative height values of the surface topography, $\sim 30-40 \mathrm{~nm}$, also indicated that the particles on the surface were not spherical. They were rather like flat elevations of the a-C:H matrix, whose surface morphology could have been influenced by small changes in the distribution and size of the $\mathrm{Cu}$ nanoparticles in the matrix.

Table 1. Roughness of the substrate and the different coating systems (C.I. $=3$ for $\sigma_{R}$ ).

\begin{tabular}{cccc}
\hline Sample & $\boldsymbol{R}_{\mathbf{a}}(\mathbf{n m})$ & $\boldsymbol{\sigma}_{\mathbf{R}}(\mathbf{n m})$ & $\boldsymbol{R}_{\mathbf{q}}(\mathbf{n m})$ \\
\hline polished Ti6Al4V substrate & 1.36 & 0.017 & 1.94 \\
$\mathrm{Ti} / \mathrm{Ti}_{x} \mathrm{C}_{\mathrm{y}} / \mathrm{a}-\mathrm{C}: \mathrm{H}: \mathrm{Ti} / \mathrm{a}-\mathrm{C}: \mathrm{H}$ & 2.23 & 0.012 & 3.61 \\
a-C:H:Cu $\mathrm{X}_{\mathrm{Cu}}=12 \%$ & 3.01 & 0.013 & 5.35 \\
a-C:H:Cu $\mathrm{X}$ Cu $=31 \%$ & 3.11 & 0.018 & 6.23 \\
a-C:H:Cu $\mathrm{X}_{\mathrm{Cu}}=55 \%$ & 4.04 & 0.014 & 6.79 \\
\hline
\end{tabular}




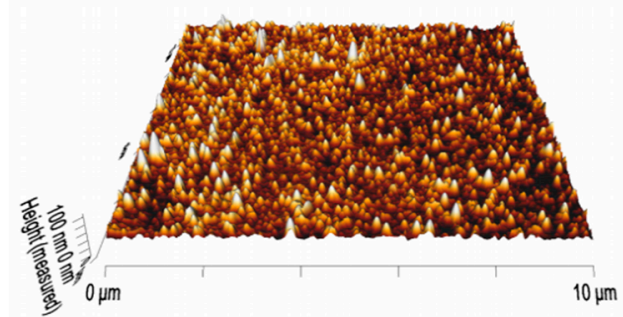

(a)

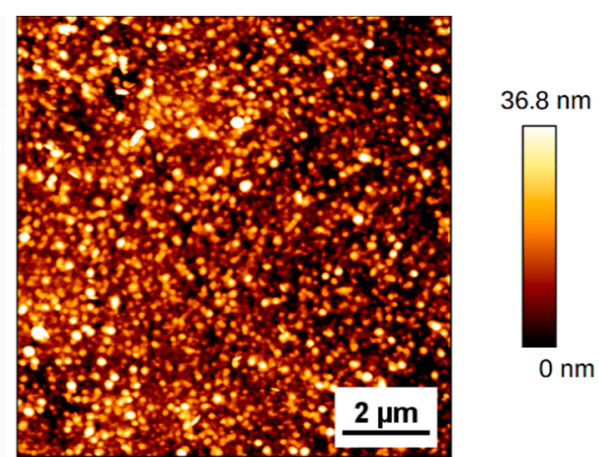

(b)

Figure 4. Exemplary AFM image of a $\mathrm{Ti} / \mathrm{Ti}_{x} \mathrm{C}_{y} / \mathrm{a}-\mathrm{C}: \mathrm{H}: \mathrm{Ti} / \mathrm{a}-\mathrm{C}: \mathrm{H} / \mathrm{a}-\mathrm{C}: \mathrm{H}: \mathrm{Cu}$ layer system with $X_{\mathrm{Cu}}=31 \%$ perspective view (a) and top view (b).

\subsection{Contact Angle}

In this section, the static contact angle of Ringer's solution on the surfaces of coated and uncoated samples is evaluated. Figure 5 gives an overview of those measured contact angles. The uncoated Ti6Al4V reference sample showed a contact angle of $56.2^{\circ} \pm 3.4^{\circ}$ and the $\mathrm{Ti} / \mathrm{Ti}_{x} \mathrm{C}_{y} / \mathrm{a}-\mathrm{C}: \mathrm{H}: \mathrm{Ti} / \mathrm{a}-\mathrm{C}: \mathrm{H}$ interlayer system showed a slightly increased contact angle of $65.6^{\circ} \pm 2.6^{\circ}$. Both samples could therefore be described as hydrophilic. When adding the a-C:H:Cu layer, even small, single-digit $\mathrm{Cu}$ contents increased the contact angle to over $90^{\circ}$ and the surfaces showed increasingly hydrophobic character, which is consistent with the literature $[63,76]$. By adding more $\mathrm{Cu}$ to the a-C:H matrix, the surface became more and more hydrophobic, as shown by the higher contact angles of up to $107.5^{\circ} \pm 1.5^{\circ}$. This relationship has already been described in the literature for Ag- and Cu-doped DLC layers and was measured independently of an applied substrate bias voltage in this work. An increase in the amount of $\mathrm{Cu}$ mole fraction mainly resulted in a reduction in the polar component of the surface energy $[76,77]$. This is explained by the increase in the sp ${ }^{2}$-hybridization of the a-C:H matrix by the $\mathrm{Cu}$ doping and formation of $\mathrm{Cu}-\mathrm{O}$ bonds. Furthermore, permanent dipoles that determine the polar part were missing because $\mathrm{Cu}$ and $\mathrm{C}$ have antibonding orbitals.

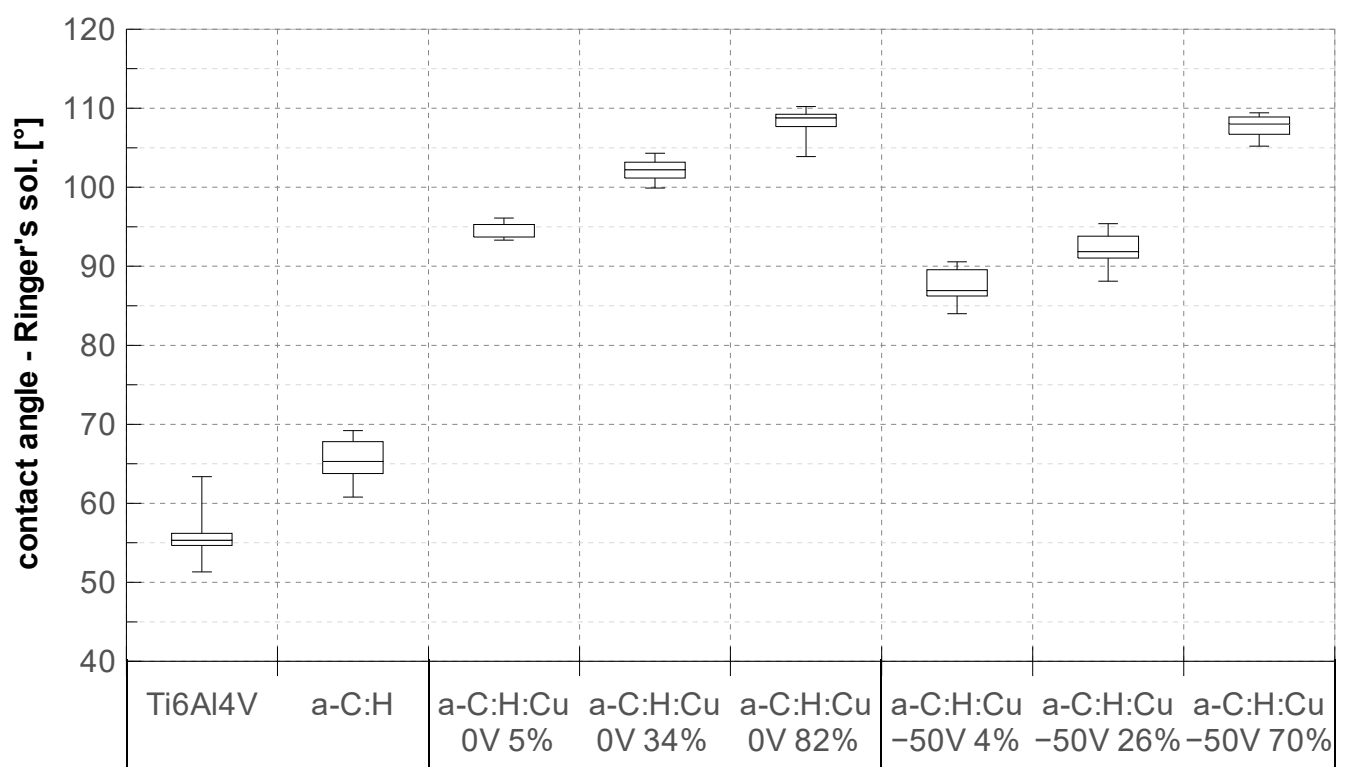

Figure 5. Contact angle of Ringer's solution on polished Ti6Al4V substrate and on the $\mathrm{Ti} / \mathrm{Ti}_{x} \mathrm{C}_{y} / \mathrm{a}-\mathrm{C}: \mathrm{H}: \mathrm{Ti} / \mathrm{a}-\mathrm{C}: \mathrm{H}$ interlayer and a-C:H:Cu layers with different $\mathrm{X}_{\mathrm{Cu}}(\%)$. a-C:H:Cu layers were deposited with $(-50 \mathrm{~V})$ and without $(0 \mathrm{~V})$ substrate bias voltage as indicated at the x-axis. (box plot). 
In conjunction with the AFM results and the relationships described by Wenzel and Cassie for textured surfaces [53], it can be concluded that this trend was also based on the increasing surface roughness.

Upon closer examination of the coatings deposited with and without applying a substrate bias voltage in Figure 6, the coatings deposited with a substrate bias voltage had a slightly reduced contact angle. This can be attributed to an increase in the $\mathrm{sp}^{3}$-content in the a-C:H matrix. With high amounts of $X_{\mathrm{Cu}}>70 \%$, no significant difference in contact angle with applied substrate bias was observed $[(p=0.204)>(\alpha=0.05)]$. It is possible that the influence of the $\mathrm{Cu}$ was predominant and thus the different contents of the carbon hybridization no longer had any significant influence on the surface energy.

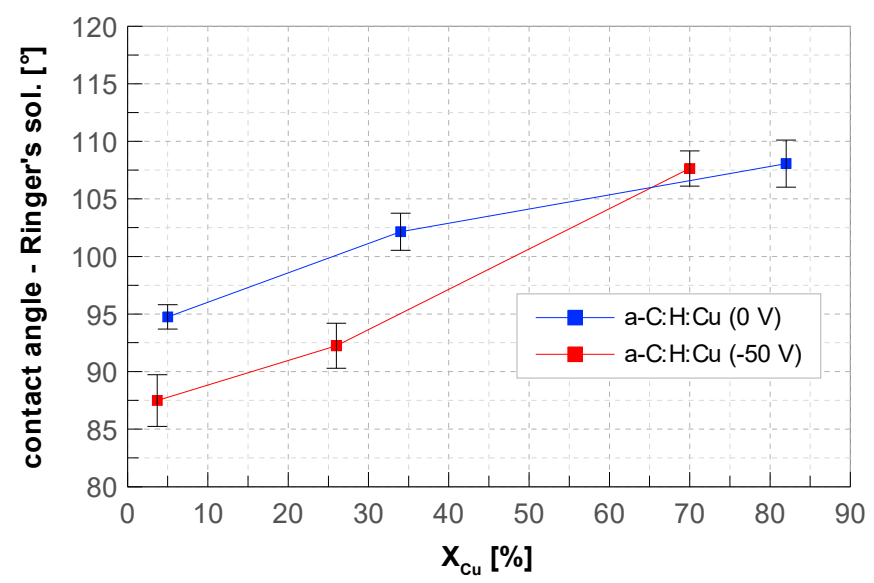

Figure 6. Comparison of contact angles of Ringer's solution on a-C:H:Cu layers deposited with ( $-50 \mathrm{~V}$ ) and without $(0 \mathrm{~V})$ substrate bias voltage; error bars indicate 5 different measured spots on each sample.

Ma et al. found that an increasing surface roughness and energy leads to increased macrophage vitality on hydrophilic DLC coatings [78]. The hemocompatibility of DLC is related to lower protein adsorption on the hydrophilic surface [78-81]. Further investigations suggest that the biocompatible properties also depend on the hydrogen content and the ratio of $\mathrm{sp}^{2} / \mathrm{sp}^{3}$ hybridization in the DLC layer. The latter characterizes the material structure with regard to graphitic and diamond-like properties. The $\mathrm{sp}^{2} / \mathrm{sp}^{3}$ ratio has been shown to affect the vitality of macrophages, as well as bacterial adhesion [82], hemocompatibility [83] and dermal fibroblast adhesion [84]. Wei et al. found that a high surface roughness of the substrate before coating, hydrophobicity, low surface free energy, low hydrogen content, and high residual stresses of the DLC layers negatively impacted cell vitality [85]. Chan et al. found that $\mathrm{Cu}$-containing DLC layers with different $w_{\mathrm{Cu}}$ significantly reduced the adhesion of E. coli on coated glass substrates. The activity of the bacteria on Cu-free DLC layers was about $40 \%$, whereas samples with a mass fraction of $w_{\mathrm{Cu}}>58.76 \%$ showed an antibacterial activity of $99.9 \%$. However, they did not demonstrate the antibacterial influence of surface roughness [55]. Tsai et al. also investigated $\mathrm{Cu}$-containing DLC layers and found an increase in the hydrophobicity of the sample surface with increasing $w_{\mathrm{Cu}}$, which is consistent with the results obtained in this work [86].

It can be concluded that a surface's biocompatibility is best in a narrow regime of hydrophilicity, at least in vitro. Accordingly, the low wettability of the a-C:H:Cu layers is critical in terms of their biocompatibility but beneficial to their antibacterial properties. A supplementary bias voltage can increase their wettability and therefore biocompatibility.

\subsection{Release Kinetics of $\mathrm{Cu}^{2+}$ Ions}

The release of $\mathrm{Cu}^{2+}$ ions (furthermore referred to as $\mathrm{Cu}$ release) was measured by the anodic stripping voltammetry (ASV) method at different time intervals. At first, an a-C:H:Cu coated sample 
with $X_{\mathrm{Cu}}=80 \%$ was put into a vessel and immersed in Ringer's solution. After a few minutes, the surface color turned blue as a result of the oxidation of the $\mathrm{Cu}$-containing surface.

After $24 \mathrm{~h}$ of immersion, EDX measurements on the sample surface were conducted showing high proportions of oxygen and chlorine (Figure 7c). SEM images revealed crystalline structures grown on the sample surface (Figure 7a,b). This suggested that the high concentration of $\mathrm{Cu}$ in the interface between the surface and Ringer's solution had formed a mixture of copper oxides, hydroxides and chlorides that had precipitated on the sample surface. The measured $\mathrm{Cu}$ molar concentration in Ringer's solution were correspondingly low, since the formation of the passivation layer inhibited the release of $\mathrm{Cu}^{2+}$ ions. In the human body there is a constant gas, mass and fluid exchange between the blood and surrounding tissue which prevents the formation of such passivation layers. Therefore, a steady exchange of the medium during the release measurements was simulated by a peristaltic pump, by which the release medium was kept in constant flow. The continuous movement of the liquid reduced the formation of the passivation layer. The influence of a regular media change was also examined. For this purpose, pure $\mathrm{Cu}$ layers of $1 \mu \mathrm{m}$ thickness were deposited on Ti6Al4V substrates by sputtering. This results in a calculated total $\mathrm{Cu}$ amount of $n_{\mathrm{Cu}}=10.47 \mu \mathrm{mol}$ and surface concentration of $110.16 \mathrm{nmol} / \mathrm{mm}^{2}$. A density of $\varrho=7 \mathrm{~g} / \mathrm{cm}^{3}$ for sputtered copper [71] was used for calculation.

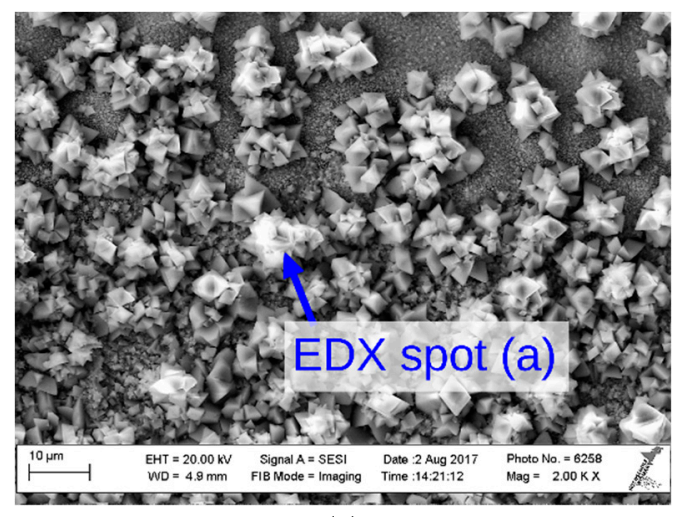

(a)

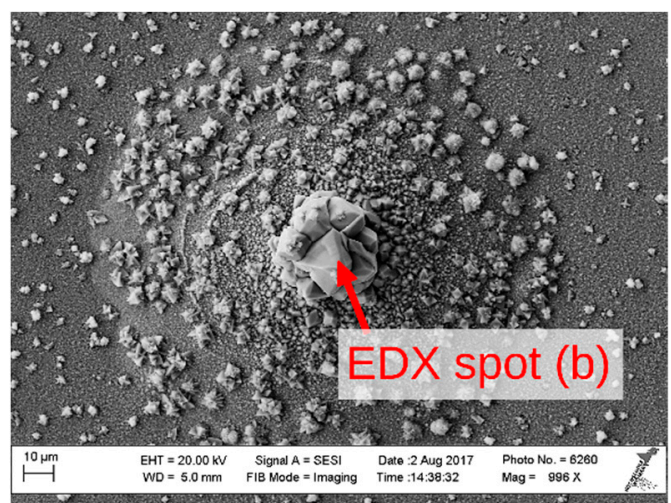

(b)

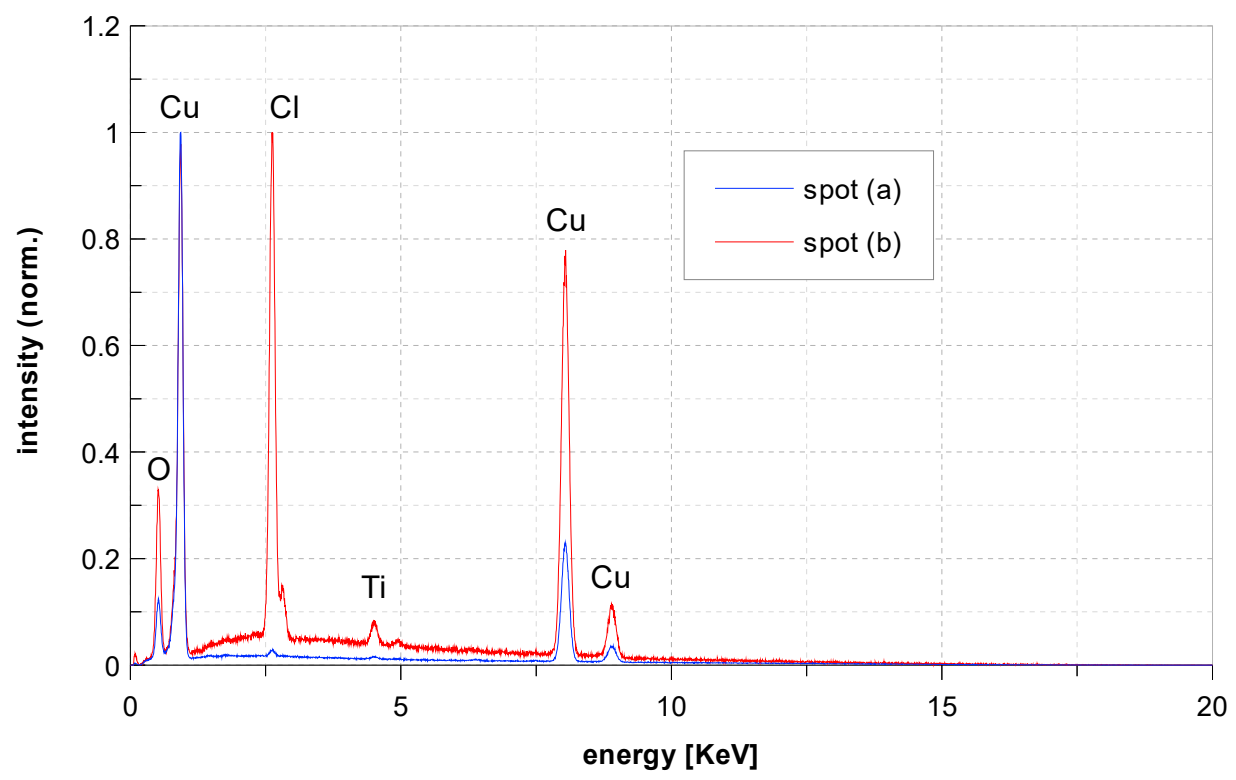

(c)

Figure 7. SEM images of the copper chloride and hydroxide crystals on an a-C:H:Cu layer with $X_{\mathrm{Cu}}=80 \%$ after immersion in Ringer's solution (spot (a), red curve) and (spot (b), blue curve) and associated EDX spectra (c). 
Two samples were immersed in Ringer's solution for 14 days. For one sample the release medium was not changed, for the second sample the medium was changed daily. A third sample was immersed for $24 \mathrm{~h}$ with an hourly medium change. The $\mathrm{Cu}$ molar concentration of Ringer's solution was measured at each medium change. The individually measured $\mathrm{Cu}$ releases and the cumulative molar concentrations are shown in Figure 8. When the release medium was not changed, the passivation layer inhibited the $\mathrm{Cu}$ release after 5 days. With a daily medium change, there was an increase in $\mathrm{Cu}$ release until the second day to $0.19 \mu \mathrm{mol} / \mathrm{L} \cdot \mathrm{mm}^{2}$. This dropped to approximately $0.05-0.1 \mu \mathrm{mol} / \mathrm{L} \cdot \mathrm{mm}^{2}$ per day and remained constant over the entire measurement period of 14 days (see Figure $8 c, d$ ). This was due to the formation of the passivation layer within the first two days, which reduced the $\mathrm{Cu}$ release in the following days.

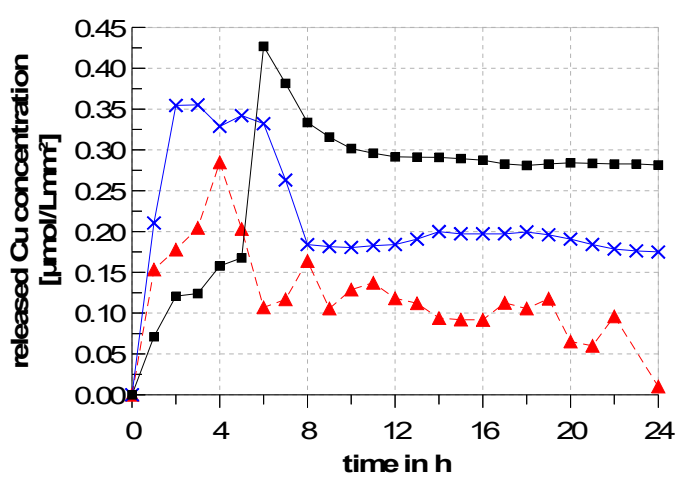

(a)

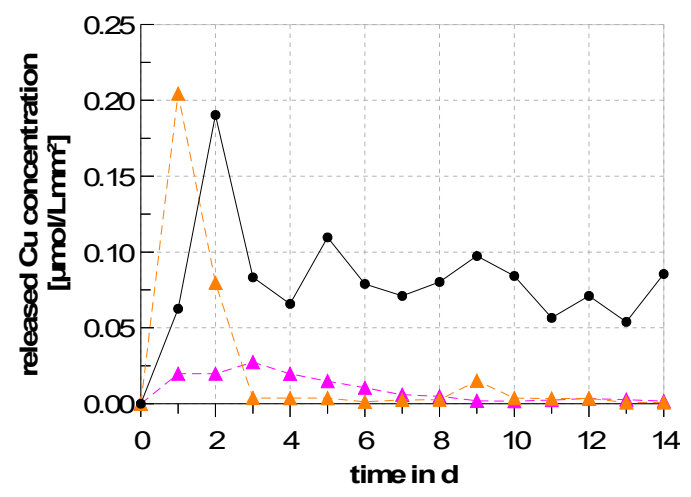

(c)

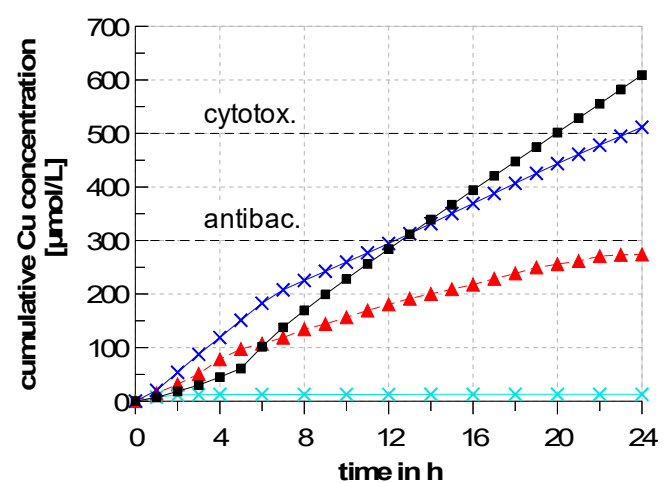

(b)

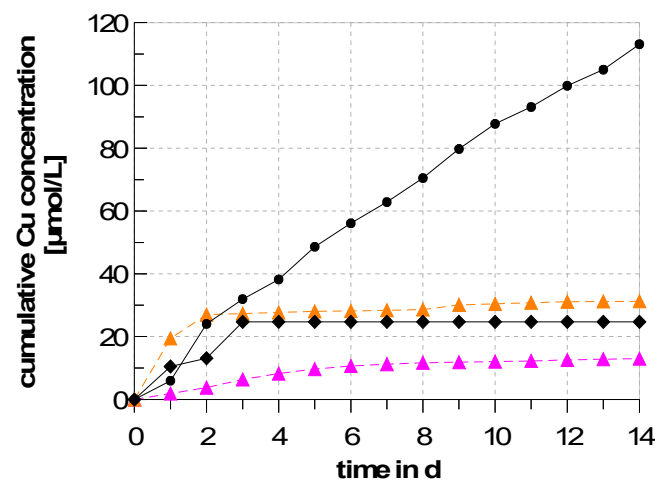

(d)
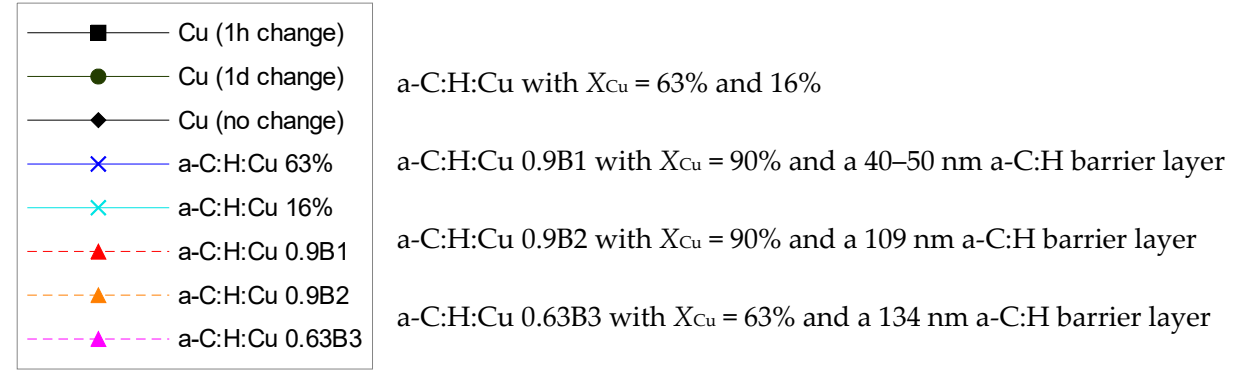

Figure 8. $\mathrm{Cu}$ release of $\mathrm{Cu}$ layers $(d=1 \mu \mathrm{m})$ with different medium change intervals and different a-C:H:Cu layer systems $\left(X_{\mathrm{Cu}}=63 \%\right.$ and 16\%) in Ringer's solution over $24 \mathrm{~h}$ (a) and corresponding cumulative $\mathrm{Cu}$ concentration (b), or over 14 days (c) and corresponding cumulative $\mathrm{Cu}$ concentration $(\mathbf{d})$, respectively.

If the release medium was changed hourly, an increased release of copper over $24 \mathrm{~h}$ was measured. Within the first $5 \mathrm{~h}$ the release increased up to $0.168 \mu \mathrm{mol} / \mathrm{Lmm}^{2}$. From $6 \mathrm{~h}$ the release increased 2.5-fold to $0.426 \mu \mathrm{mol} / \mathrm{L} \cdot \mathrm{mm}^{2}$ and then dropped to an approximately constant $0.28 \mu \mathrm{m} / \mathrm{L} \cdot \mathrm{mm}^{2}(\mathrm{see}$ 
Figure 8a). The reasons for the strong increase in $\mathrm{Cu}$ release that occurred within the first $6 \mathrm{~h}$ or 2 days should be further investigated. It is possible that with the dissolution of $\mathrm{Cu}$ the roughness of the surface increased. This expanded the contact area between the $\mathrm{Cu}$ layer and the release medium, thereby enhancing the $\mathrm{Cu}$ release. The subsequent decrease of the $\mathrm{Cu}$ release can again be explained by the formation of the passivation layer. A direct comparison of both the $24 \mathrm{~h}$ and 14 days samples shows that the hourly medium change led to an approximately 4 -fold higher release. If one considers the cumulative molar concentration in Figure $8 \mathrm{~b}$ it becomes clear that more than the same amount of material was released $(0.14 \mathrm{mmol} / \mathrm{L})$ after $7 \mathrm{~h}$ with an hourly medium change as was released after 14 days with a daily medium change $(0.11 \mathrm{mmol} / \mathrm{L})$. Overall, a cumulative molar concentration of $0.61 \mathrm{mmol} / \mathrm{L}$ was achieved after $24 \mathrm{~h}$. This corresponds to a released amount of $n_{\mathrm{Cu}, \mathrm{R}}=6.1 \mu \mathrm{mol}$ and thus about $58 \%$ of the calculated total $\mathrm{Cu}$ amount of the $\mathrm{Cu}$ layer $\left(n_{\mathrm{Cu}}=10.47 \mu \mathrm{mol}\right)$. With this $\mathrm{Cu}$ layer, the antibacterial concentration for Staphylococcus aureus in PBS (phosphate buffered saline) of $300 \mu \mathrm{mol} / \mathrm{L}$ was exceeded after $13 \mathrm{~h}$ and the cytotoxic concentration of $500 \mu \mathrm{mol} / \mathrm{L}$ was exceeded after $20 \mathrm{~h} \mathrm{[67].}$

To study the $\mathrm{Cu}$ release from a-C:H:Cu layers, two samples were prepared with $X_{\mathrm{Cu}}=63 \%$ (a-C:H: $\left.\mathrm{Cu}_{0.63}\right)$ and $\mathrm{X}_{\mathrm{Cu}}=16 \%\left(\mathrm{a}-\mathrm{C}: \mathrm{H}: \mathrm{Cu}_{0.16}\right)$ and immersed in Ringer's solution for $24 \mathrm{~h}$. The time intervals of the measured $\mathrm{Cu}$ releases are shown in Figure 8a. For both a-C:H:Cu layers, the $\mathrm{Cu}$ release was the highest in the first $5 \mathrm{~h}\left(0.35\right.$ and $\left.0.075 \mu \mathrm{mol} / \mathrm{Lmm}^{2}\right)$, in contrast to the abrupt increase after just $6 \mathrm{~h}$ for the pure $\mathrm{Cu}$ layer. This can be explained by the weakly bounded, near-surface $\mathrm{Cu}$ nanoparticles in the a-C:H matrix, which rapidly desorbed. At the same time, the $\mathrm{Cu}$ nanoparticles had a higher surface area-volume ratio than a closed $\mathrm{Cu}$ layer. After $5 \mathrm{~h}$, the $\mathrm{Cu}$ release of the sample a-C:H:Cu $\mathrm{Cu}_{0.63}$ dropped to an approximately constant $0.18-0.2 \mu \mathrm{mol} / \mathrm{Lmm}^{2}$ and was thus below that of a pure $\mathrm{Cu}$ layer. For sample a-C:H: $\mathrm{Cu}_{0.16}$, the $\mathrm{Cu}$ release stopped after $6 \mathrm{~h}$. This difference between the two a-C:H:Cu layers can be explained by the fact that after dissolving the $\mathrm{Cu}$ nanoparticles at high $\mathrm{X}_{\mathrm{Cu}}$ a porous a-C:H matrix remained. On the one hand, the release medium could penetrate through these pores and thus dissolve $\mathrm{Cu}$ in greater depth of the a-C:H:Cu coating; on the other hand, $\mathrm{Cu}$ located in deeper layer regions could diffuse through the pores to the surface. The corresponding chemical mechanism was the oxidation of the $\mathrm{Cu}$ nanoparticles by hydronium ions and dissolved oxygen in the release medium according to the reaction equation:

$$
\begin{gathered}
2 \mathrm{Cu}(\mathrm{s})+4 \mathrm{H}_{3} \mathrm{O}^{+}+\mathrm{O}_{2}(\mathrm{aq})+\rightarrow \mathrm{Cu}^{2+}(\mathrm{aq})+6 \mathrm{H}_{2} \mathrm{O} \\
(\mathrm{aq}) \text { aqua }=\text { dissolved } \quad(\mathrm{s}) \text { solid }=\text { film }
\end{gathered}
$$

Considering the cumulative molar $\mathrm{Cu}$ concentration in Figure $8 \mathrm{~b}$, it becomes clear that the a-C:H: $\mathrm{Cu}_{0.63}$ layer, despite its low $\mathrm{Cu}$ amount of $n_{\mathrm{Cu}}=6.6 \mu \mathrm{mol}$, released $0.5 \mathrm{mmol} / \mathrm{L}$ within $24 \mathrm{~h}$ $\left(n_{\mathrm{Cu}, \mathrm{R}}=5 \mu \mathrm{mol}\right)$, which is an almost equal amount of copper released as the pure $\mathrm{Cu}$ layer. This was mainly due to the higher release within the first $6 \mathrm{~h}$. The a-C:H:Cu $\mathrm{Cu}_{0.63}$ layer exceeded the antibacterial concentration of $300 \mu \mathrm{mol} / \mathrm{L}$ for $\mathrm{S}$. aureus after $13 \mathrm{~h}$. The a-C:H:Cu 0.16 layer released only $0.0126 \mathrm{mmol} / \mathrm{L}\left(n_{\mathrm{Cu}, \mathrm{R}}=0.126 \mu \mathrm{mol}\right)$ within $24 \mathrm{~h}$ and did not reach an antibacterial concentration in the observed period of time.

EDX measurements showed $\mathrm{Cu}$ mole fractions of $X_{\mathrm{Cu}, 0.63}=19 \%$ and $X_{\mathrm{Cu}, 0.16}=15 \%$ for the a-C:H:Cu layers after immersion. Thus, for the a-C:H: $\mathrm{Cu}_{0.63}$ layer, $\mathrm{X}_{\mathrm{Cu}}$ was reduced by 44 percentage points and consequently $70 \%$ of the total amount of contained $\mathrm{Cu}$ was released. The EDX result is in good agreement with the measured amount of $\mathrm{Cu}$ release compared to the original total $\mathrm{Cu}$ amount of the layer $\left(n_{\mathrm{Cu}, \mathrm{R}} / n_{\mathrm{Cu}}=6.6 \mu \mathrm{mol} / 5 \mu \mathrm{mol} \times 100 \%=76 \%\right.$ of the original total amount of $\mathrm{Cu}$ ). The small discrepancy can be explained by the fact that the EDX measures an integral signal which is depth-dependent. It is possible that $\mathrm{Cu}$ that previously was deeper in the a-C:H:Cu layer diffused to the surface and thereby amplified the $\mathrm{Cu}$ signal in the spectrum. Furthermore, the calculated total $\mathrm{Cu}$ amount of the layers was only estimated values and subject to errors.

Additionally, the influence of an a-C:H barrier layer on the $\mathrm{Cu}$ release was investigated. For this purpose, the $\mathrm{C}_{2} \mathrm{H}_{2}$ partial pressure was increased towards the end of the deposition phase. In this 
way, an a-C:H barrier layer (B1) of 40-50 nm thickness was deposited on an a-C:H:Cu layer with $X_{\mathrm{Cu}} \approx 90 \%$ (Figure 9a). Figure $8 \mathrm{a}$ shows an unsteady $\mathrm{Cu}$ release for the sample a-C:H:Cu $0.9 B 1$ within the first $24 \mathrm{~h}$. Within the first $4 \mathrm{~h}$, the $\mathrm{Cu}$ release increased up to $0.285 \mu \mathrm{mol} / \mathrm{Lmm}^{2}$ and then dropped to values around $0.1 \mu \mathrm{mol} / \mathrm{Lmm}^{2}$. Over the last $20 \mathrm{~h}$ the release showed a constant reduction to $0.0077 \mu \mathrm{mol} / \mathrm{Lmm}^{2}$ and after $24 \mathrm{~h}$ a cumulative molar $\mathrm{Cu}$ concentration of $0.27 \mathrm{mmol} / \mathrm{L}$ $\left(n_{\mathrm{Cu}, \mathrm{R}}=2.7 \mu \mathrm{mol}\right)$ was released, which was just below the antibacterial concentration of $300 \mu \mathrm{mol} / \mathrm{L}$ in PBS. Accordingly, the cumulative $\mathrm{Cu}$ release was halved when compared to the a-C:H:Cu $\mathrm{Cu}_{0.63}$ layer without the barrier layer. Thus, the a-C:H barrier layer effectively reduced the release of the copper.

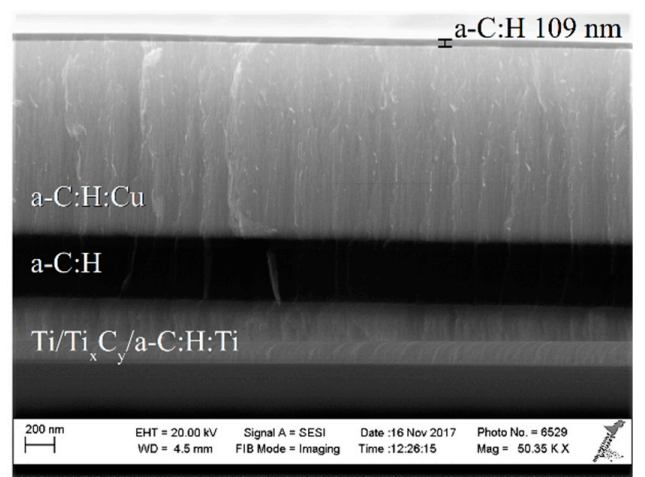

(a)

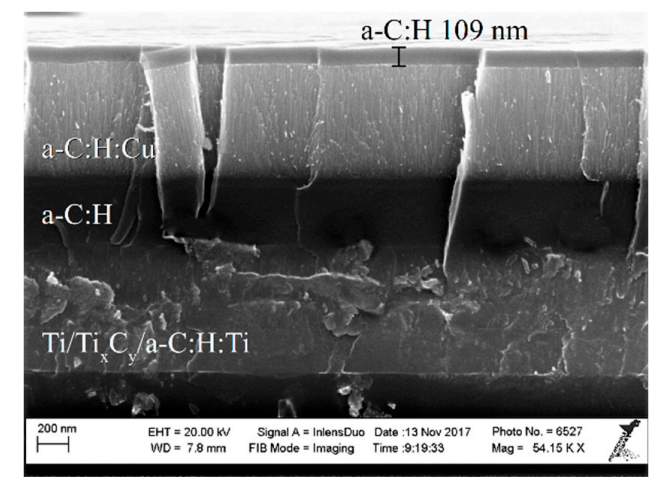

(b)

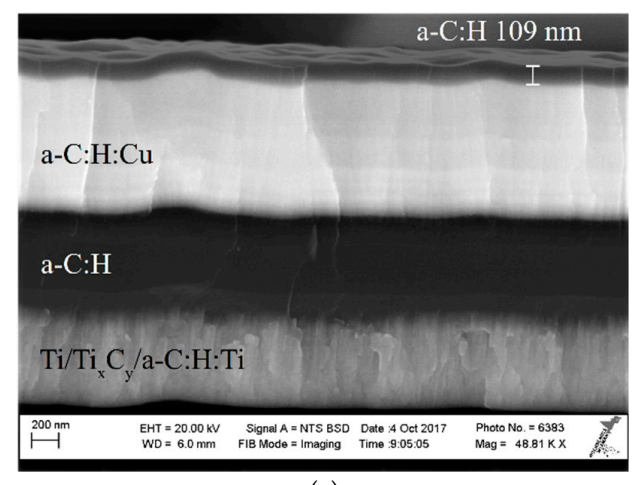

(c)

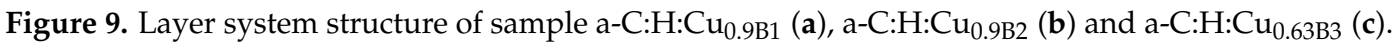

Next, the thickness of the a-C:H barrier layer (B2) was increased to $109 \mathrm{~nm}$ (Figure 9b) and its $\mathrm{Cu}$ release was measured over 14 days with a daily medium change (Figure $8 \mathrm{c}$ ). The sample a-C:H:Cu $\mathrm{u}_{0.9 \mathrm{~B} 2}$ showed the highest $\mathrm{Cu}$ release within the first $24 \mathrm{~h}\left(0.2 \mu \mathrm{mol} / \mathrm{L} \cdot \mathrm{mm}^{2}\right)$, which was in the order of the previous sample a-C:H:Cu $\mathrm{Cu}_{0.9 \mathrm{~B} 1}$ with a barrier layer of $40-50 \mathrm{~nm}$ thickness. After 3 days, the $\mathrm{Cu}$ release was greatly reduced to values around $3.5 \times 10^{-3} \mu \mathrm{mol} / \mathrm{Lmm}^{2}$, and after 14 days a cumulative molar $\mathrm{Cu}$ concentration of $0.0313 \mathrm{mmol} / \mathrm{L}\left(n_{\mathrm{Cu}, \mathrm{R}}=0.313 \mu \mathrm{mol}\right)$ was released. As a result, the thicker a-C:H barrier layer significantly reduced the $\mathrm{Cu}$ release when compared to the pure $\mathrm{Cu}$ layer over 14 days (Figure 8c,d).

Furthermore, an a-C:H barrier layer (B3) of $134 \mathrm{~nm}$ thickness was deposited onto an a-C:H:Cu $\mathrm{Cu}_{0.63}$ layer (Figure 9c). This reduced the $\mathrm{Cu}$ release by two orders of magnitude when compared to the layer systems without a barrier layer. The highest $\mathrm{Cu}$ release was measured after 3 days with 0.027 $\mu \mathrm{mol} / \mathrm{Lmm}^{2}$, which decreased approximately linearly to $1.7 \times 10^{-3}-3.4 \times 10^{-3} \mu \mathrm{mol} / \mathrm{L} \cdot \mathrm{mm}^{2}$ within the next 5 days and then remained constant. After 14 days, a cumulative molar $\mathrm{Cu}$ concentration of $0.0129 \mathrm{mmol} / \mathrm{L}\left(n_{\mathrm{Cu}, \mathrm{R}}=0.129 \mu \mathrm{mol}\right)$ was released from the sample a-C:H:Cu $\mathrm{u}_{0.63 \mathrm{~B} 3}$ with the a-C:H barrier layer. The cumulative $\mathrm{Cu}$ concentrations of all samples with a barrier layer were well below the antibacterial concentration of $300 \mu \mathrm{mol} / \mathrm{L}$. The a-C:H barrier layer was therefore suitable for delaying $\mathrm{Cu}$ release. However, the concentration was potentially too low for antibacterial activity. 
Furthermore, it is clear that $\mathrm{X}_{\mathrm{Cu}}$ of the a-C:H:Cu layer and the thickness of the a-C:H barrier layer were the key factors for controlling the $\mathrm{Cu}$ release. In addition, the thickness of the a-C:H:Cu layer influenced the $\mathrm{Cu}$ release by different diffusion, but a deeper discussion goes beyond the scope of this paper. It should be noted that the additional a-C:H barrier layer prevented the formation of a passivation layer. Overall, in the period under consideration ( $24 \mathrm{~h}$ or 14 days), none of the layers released the $\mathrm{Cu}$ completely or reached the end of the $\mathrm{Cu}$ release. Therefore, further investigations with longer measurement times are necessary in this regard.

Stranak et al. investigated the $\mathrm{Cu}$ release of three different $\mathrm{Ti} / \mathrm{Cu}$ mixed layers in $700 \mu \mathrm{L}$ DMEM (Dulbecco's Modified Eagle Medium (DMEM)) at $37^{\circ} \mathrm{C}$ [23]:

- $\quad$ top-layer $\left(X_{\mathrm{Cu}}=90 \%, n_{\mathrm{Cu}}=1.225 \mu \mathrm{mol}\right)$;

- $\quad$ bottom-layer $\left(X_{\mathrm{Cu}}=55 \%, n_{\mathrm{Cu}}=2.31 \mu \mathrm{mol}\right)$;

- dual-layer $\left(n_{\mathrm{Cu}}=3.71 \mu \mathrm{mol}\right)$ consisting of top and bottom layer.

The top layer released most of the $\mathrm{Cu}$ within $24 \mathrm{~h}$ and reached a $\mathrm{Cu}$ concentration of $1.85 \mathrm{mmol} / \mathrm{L}$ $\left(6.71 \mu \mathrm{mol} / \mathrm{L} \cdot \mathrm{mm}^{2}\right)$. Although the total $\mathrm{Cu}$ concentration achieved was one order of magnitude higher than that of the $\mathrm{Cu}$ layer and a-C:H:Cu $\mathrm{Cu}_{0.63}$ layer investigated in this work (500 and $610 \mu \mathrm{mol} / \mathrm{L}$ ), when regarding the different sample surface area, their values do not differ greatly $\left(5.26 \mu \mathrm{mol} / \mathrm{L} \cdot \mathrm{mm}^{2}\right.$ and $6.42 \mu \mathrm{mol} / \mathrm{Lmm}^{2}$ ). In contrast, only a fraction of the amount of $\mathrm{Cu}$ contained in the bottom layer was released within $24 \mathrm{~h}$, resulting in a Cu concentration of $1 \mathrm{mmol} / \mathrm{L}\left(3.63 \mu \mathrm{mol} / \mathrm{L} \cdot \mathrm{mm}^{2}\right)$. Further, only a small portion of the $\mathrm{Cu}\left(<0.901 \mu \mathrm{mol} / \mathrm{L} \cdot \mathrm{mm}^{2}\right)$ was released over the measurement period of 10 days. Therefore, in this case, the $\mathrm{Cu}$ release was also slowed down by a mixed layer of $\mathrm{Ti}$ and $\mathrm{Cu}$. The different $\mathrm{Cu}$ release of top-layer and bottom-layer is also discussed by Stranak et al. in relation to their different morphology. However, they did not take into account the different $\mathrm{Cu}$ mole fractions of the layers, which can have a far greater influence. The combination of these two layers as a dual-layer reached a $\mathrm{Cu}$ concentration of $4.7 \mathrm{mmol} / \mathrm{L}\left(17.04 \mu \mathrm{mol} / \mathrm{L} \cdot \mathrm{mm}^{2}\right)$ within $24 \mathrm{~h}$, releasing $n_{\mathrm{Cu}, \mathrm{R}}=3.29 \mu \mathrm{mol}$ or $89 \%$ of the total $\mathrm{Cu}$. This release is thus three times as high as that of the $\mathrm{Cu}$ and a-C:H:Cu $\mathrm{Cu}_{0.63}$ layer presented in this work. After $48 \mathrm{~h}$, a Cu concentration of $400 \mu \mathrm{mol} / \mathrm{L}$ $\left(1.45 \mu \mathrm{mol} / \mathrm{L} \cdot \mathrm{mm}^{2}\right)$ was measured, which steadily decreased during the 50 days.

In their previous work, Stranak et al. examined three Ti/Cu layers produced by DC-MS, dual-MS, and dual-HiPIMS [71]. The total amount of $\mathrm{Cu}$ in the DC-MS and dual-MS layers was 0.94-1.1 $\mu \mathrm{mol}$, while that of the dual-HiPIMS layer was $3.15 \mu$ mol. Again, the $\mathrm{Cu}$ release was highest within the first $24 \mathrm{~h}$. The dual-MS layer did not release a recognizable amount of $\mathrm{Cu}$, while the DC-MS layer released $750 \mu \mathrm{mol} / \mathrm{L}\left(2.89 \mu \mathrm{mol} / \mathrm{L} \cdot \mathrm{mm}^{2}\right)$ and thus $0.525 \mu \mathrm{mol}$ or $56 \%$ of the total amount of $\mathrm{Cu}$. No further $\mathrm{Cu}$ release of the sample was measured after $24 \mathrm{~h}$. Due to the low $\mathrm{Cu}$ release, there was no antibacterial activity of both layers against S. epidermidis or S. aureus in DMEM, although the Cu concentration of the DC-MS layer was above the antibacterial Cu concentration of $300 \mu \mathrm{mol} / \mathrm{L}$ in PBS [67]. This can be attributed to the fact that DMEM promotes bacterial growth as a nutrient medium. At the same time, in cell culture media $\mathrm{Cu}$ ions are bound to proteins and amino acids in the medium, whereby they no longer have an antibacterial effect.

By contrast, the dual-HiPIMS layer released $6 \mathrm{mmol} / \mathrm{L}\left(23.15 \mu \mathrm{mol} / \mathrm{Lmm}^{2}\right)$ after $24 \mathrm{~h}$ and thus $n_{\mathrm{Cu}, \mathrm{R}}=4.2 \mu \mathrm{mol}$. It becomes clear that all $\mathrm{Cu}$ was released within the first $24 \mathrm{~h}$. The enhanced $\mathrm{Cu}$ release of the dual-HiPIMS layer is also explained by the altered crystallographic properties. It led to an antibacterial effect of the layer against S. epidermidis and S. aureus in DMEM, which was higher in the planktonic form than in the biofilm-forming. However, their work does not deal with the different $\mathrm{Cu}$ mole fraction of the individual layers, which may also be the cause of the different release.

Furthermore, when discussing the results from the literature, it should be noted that different release media volumes were used for $\mathrm{Cu}$ release measurements $(10 \mathrm{~mL}, 5 \mathrm{~mL}, 700 \mu \mathrm{L})$. Assuming there were equal amounts of dissolved $\mathrm{Cu}$, this resulted in differences in measured concentrations, but when the released $\mathrm{Cu}$ concentrations are correlated to the release media volume, the results draw a different picture (Figure 10). 


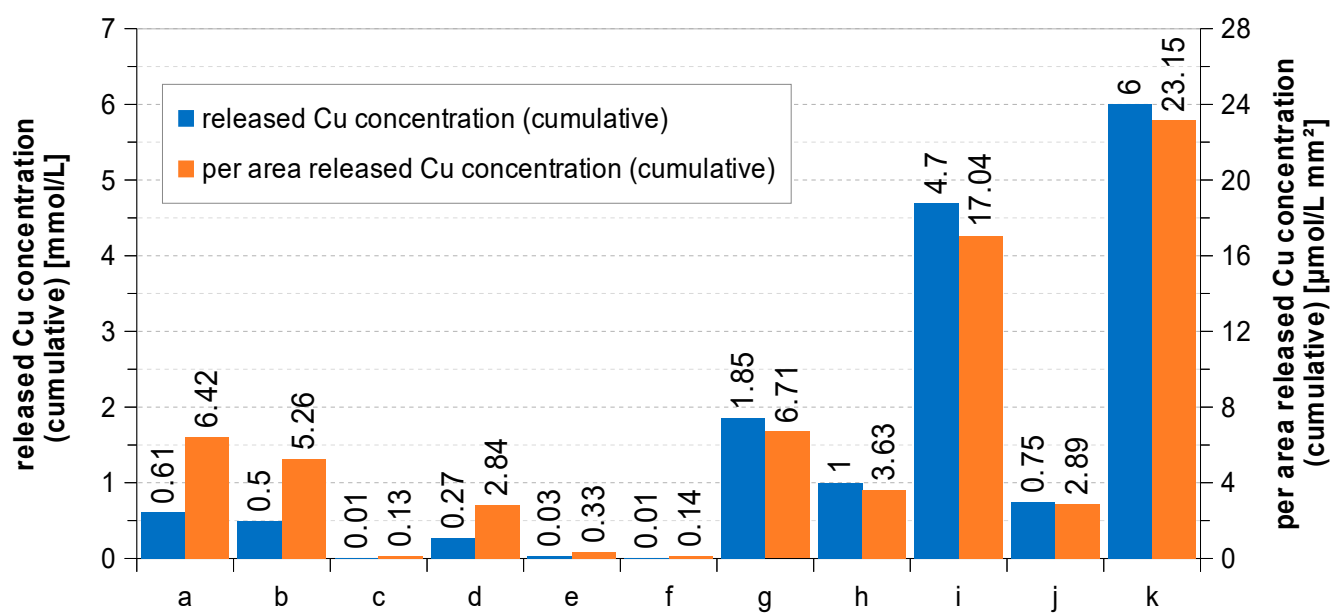

(a)

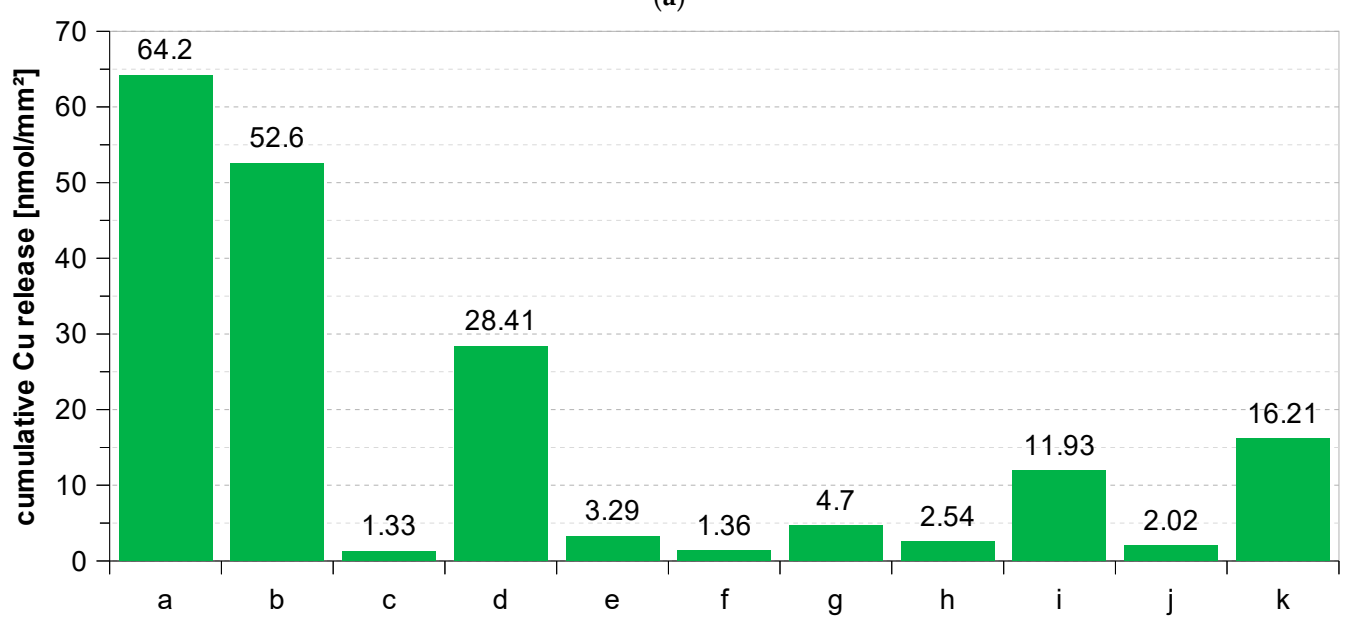

(b)

Coatings in this work (Ringer-sol.)

$\begin{array}{ll}\text { a: } \mathrm{Cu} & 24 \mathrm{~h} \\ \text { b: a-C:H:Cu0.63 } & 24 \mathrm{~h} \\ \text { c: a-C:H:Cu0.16 } & 24 \mathrm{~h} \\ \text { d: a-C:H:Cu0.63B } & 14 \text { days } \\ \text { e: a-C:H:Cu0.9B1 } & 14 \text { days } \\ \text { f: a-C:H:Cu0.9B2 } & 14 \text { days }\end{array}$

Coatings from Stranak et al. (DMEM) [23]

$\begin{array}{ll}\text { g: top-layer } & 24 \mathrm{~h} \\ \text { h: bottom-layer } & 24 \mathrm{~h} \\ \text { i: dual-layer } & 24 \mathrm{~h}\end{array}$

Coatings from Stranak et al. (DMEM) [71]

$\begin{array}{ll}\text { j: DC-MS } & 24 \mathrm{~h} \\ \text { k: dual-HiPIMS } & 24 \mathrm{~h}\end{array}$

Figure 10. Comparison of the released $\mathrm{Cu}$ concentration (cumulative) of different $\mathrm{Cu}$ composite layers (a) and comparison of the area-related and volume-adjusted $\mathrm{Cu}$ release (cumulative) of different $\mathrm{Cu}$ composite layers after $24 \mathrm{~h}$ or 14 days (b).

It is clear from the cited work that the control of the release kinetics of the antibacterial substance in medical use is crucial. It must be large enough to stop infection, while maintaining the vitality of the body's own cells. For this purpose, this work can make a significant contribution since it determines how the $\mathrm{Cu}$ release can be controlled by a nanoconfigured layer structure. Based on this, coating systems can be modified, expanded and adapted to specific medical requirements. For a final assessment, microbiological studies on the antibacterial efficacy and cytotoxicity of the a-C:H:Cu layers are missing. 


\subsection{GDOES Depth Profiles}

The GDOES depth profiles in Figure 11 show the distinct layer structures. The layer system consists of $\mathrm{C}, \mathrm{H}(\mathrm{a}-\mathrm{C}: \mathrm{H})$ and $\mathrm{Cu}$, as well as significant amounts of $\mathrm{O}$ as a contaminant. When reaching the substrate, elements of the Ti6Al4V $(\mathrm{Ti}, \mathrm{Al}, \mathrm{V})$ were found. Beginning from the Ti6Al4V substrate (right side), the carbon and hydrogen peaks rose as a result of the gradient $\mathrm{C}$ deposition from Ti to $\mathrm{Ti}_{x} \mathrm{C}_{y}$ and a-C:H:Ti. The high amount of $\mathrm{H}$ can be attributed to low hydrocarbon ion energies because no substrate voltage was used during this deposition step. When switching to the a-C:H deposition in the rf-magPECVD process, the hydrogen signal decreased. This was a result of the high substrate bias voltage of $1 \mathrm{kV}$ during a-C:H deposition that resulted in high hydrocarbon ion energies, which is known to lower the $\mathrm{H}$ deposition in a-C:H coatings [87]. When reaching the a-C:H:Cu layer, the copper content showed a chemical gradient that was a result of the gradient copper deposition process which was used to enhance the adhesion of the a-C:H:Cu to the a-C:H layer. Further information regarding the graded copper deposition is summarized in a further paper [73]. Following that procedure, the copper was homogeneously distributed in the a-C:H:Cu coatings over coating depth. When comparing the GDOES results of the samples with the a-C:H:Cu $\mathrm{Cu}_{0.63}$ layer before and after release measurement (Figure 11a,b), one can see the reduced amount of copper in the a-C:H:Cu $\mathrm{Cu}_{0.63}$ layer after release measurement.

In the case of the sample with the barrier layer (Figure $11 \mathrm{c}, \mathrm{d}$ ), the copper content was reduced to 0 at the surface while the carbon content remained high. It is evident that the amount of copper was not significantly reduced, which is consistent with the release measurements in the previous section.

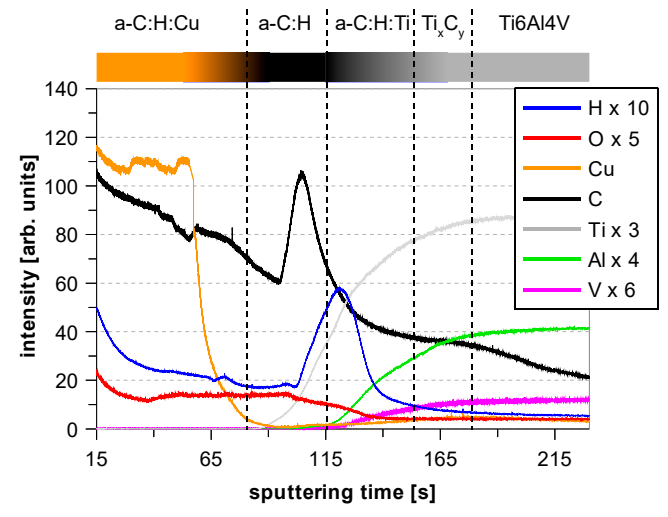

(a)

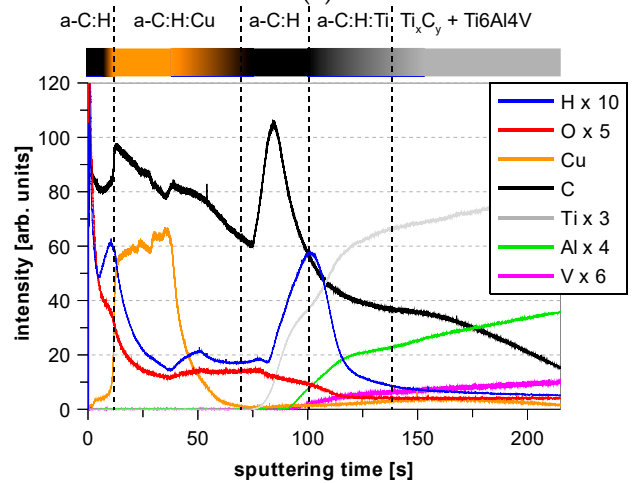

(c)

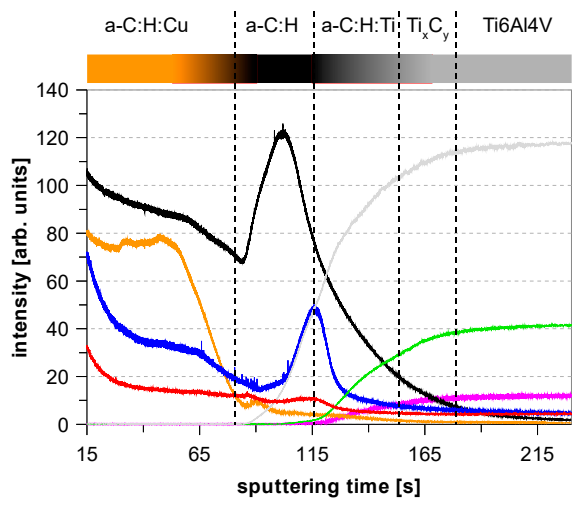

(b)

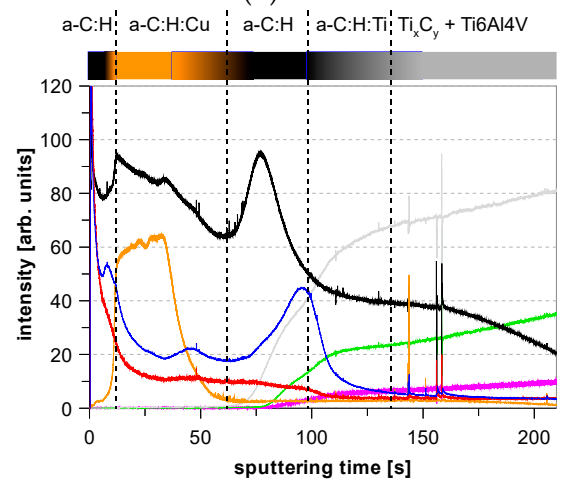

(d)

Figure 11. GDOES depth profile of a $\mathrm{Ti} / \mathrm{Ti}_{x} \mathrm{C}_{y} / \mathrm{a}-\mathrm{C}: \mathrm{H}: \mathrm{Ti} / \mathrm{a}-\mathrm{C}: \mathrm{H} / \mathrm{a}-\mathrm{C}: \mathrm{H}: \mathrm{Cu}$ layer system with a-C:H: $\mathrm{Cu}_{0.63}$ containing $\mathrm{X}_{\mathrm{Cu}}=63 \%$ before (a) and after (b) release measurement, as well as a-C:H: $\mathrm{Cu}_{0.63 \mathrm{~B} 3}$ with an a-C:H barrier layer before (c) and after $(\mathbf{d})$ release measurement. 


\section{Conclusions}

In this paper we reported on the surface properties and the time-resolved release kinetics of copper ions $\left(\mathrm{Cu}^{2+}\right)$ from a-C:H:Cu coatings that were deposited onto Ti6Al4V substrates, and how the release can be controlled by an a-C:H barrier layer.

$\mathrm{Cu}$ containing a-C:H:Cu composite coatings were deposited using a hybrid RF-PVD/PECVD process and grown surface topography, and $\mathrm{Cu}$ release in Ringer's solution was investigated. The deposited films consisted of three layers: the $\mathrm{Ti} / \mathrm{Ti}_{x} \mathrm{C}_{y} / \mathrm{a}-\mathrm{C}: \mathrm{H}: \mathrm{Ti} / \mathrm{a}-\mathrm{C}: \mathrm{H}$ interlayer, the $\mathrm{Cu}$-containing a-C:H:Cu layer and an a-C:H barrier layer. The performed AFM measurements showed an increasing roughness of the sample surface with increasing $X_{\mathrm{Cu}}$ in the a-C:H:Cu layer, which is consistent with the literature. This can be attributed to the size of $\mathrm{Cu}$ nanoparticles embedded into the a-C:H matrix. The static contact angle of Ringer's solution on the layers also increased with increasing $X_{\mathrm{Cu}}$ and, therefore, $\mathrm{Cu}$ nanoparticle size. Thus, the wetting behaviour changed from hydrophilic (polished Ti6Al4V and Cu-free a-C:H layer) to increasingly hydrophobic (a-C:H:Cu). Additionally, an influence of the substrate bias voltage on the wettability was determined. This could be related to a change in content of $\mathrm{sp}^{3}$ and $\mathrm{sp}^{2}$ hybridization in the a-C:H matrix [77,87]. The low wettability of the a-C:H:Cu layers is critical in terms of their biocompatibility, but beneficial to their antibacterial properties.

The release of $\mathrm{Cu}^{2+}$ ions from sputtered $\mathrm{Cu}$ layers and a-C:H:Cu layers with different $\mathrm{X}_{\mathrm{Cu}}$ in Ringer's solution was examined. As a reference, a pure $\mathrm{Cu}$ layer was used to investigate the maximum possible $\mathrm{Cu}$ release. When using a stationary solution, a passivation layer of sparingly soluble copper oxides, hydroxides and chlorides precipitated on the surface of the $\mathrm{Cu}$ and a-C:H:Cu layers, which inhibited further release of $\mathrm{Cu}$. This can be prevented by regularly changing the release medium and generating a continuous flow of the medium.

It has been shown that the release kinetics of the $\mathrm{Cu}^{2+}$ ions from the a-C:H:Cu layers in the medium over 14 days could be controlled by adjusting $\mathrm{X}_{\mathrm{Cu}}$ in the a-C:H:Cu layers and the thickness of an additional a-C:H barrier layer. This enabled a release over a long period of time. The pure $\mathrm{Cu}$ layer and a-C:H:Cu $\mathrm{Cu}_{0.63}$ layer reached a potential antibacterial $\mathrm{Cu}$ concentration for S. aureus in PBS of at least $300 \mu \mathrm{mol} / \mathrm{L}$ [67] after $13 \mathrm{~h}$. In contrast, this antibacterial concentration was not reached for the $\mathrm{a}-\mathrm{C}: \mathrm{H}: \mathrm{Cu}_{0.16}$ layer or the samples with a barrier layer in the period considered.

Author Contributions: Conceptualization, M.W. (Marion Wienecke), D.B. and M.W. (Mareike Warkentin); Data Curation, S.N.; Formal Analysis, S.N., K.R., S.G. and P.C.; Funding Acquisition, M.W. (Marion Wienecke); Investigation, S.N.; Methodology, S.N.; Project Administration, M.W. (Marion Wienecke); Resources, M.W. (Marion Wienecke); Supervision, J.H., M.W. (Marion Wienecke), D.B. and M.W. (Mareike Warkentin); Validation, J.H.; Visualization, S.N.; Writing-Original Draft, S.N.; Writing-Review \& Editing, J.H., K.R., S.G. and P.C.

Funding: This research was funded by the German Federal Ministry of Education and Research within the BMBF-project Nano4Med No. 03FH005IX5.

Conflicts of Interest: The authors declare no conflict of interest.

\section{References}

1. Aslam, S.; Darouiche, R.O. Prosthetic joint infection. Curr. Infect. Dis. Rep. 2012, 14, 551-557. [CrossRef] [PubMed]

2. Pulido, L.; Ghanem, E.; Joshi, A.; Purtill, J.J.; Parvizi, J. Periprosthetic joint infection: The incidence, timing, and predisposing factors. Clin. Orthop. Relat. Res. 2008, 466, 1710-1715. [CrossRef] [PubMed]

3. Neogi, D.S.; Yadav, C.S.; Madhuri V, P. Risk factors associated with acute hip prosthetic joint infections and outcome of treatment with a rifampin-based regimen. Acta Orthop. 2008, 79, 454-457. [CrossRef] [PubMed]

4. Phillips, J.E.; Crane, T.P.; Noy, M.; Elliott, T.S.J.; Grimer, R.J. The incidence of deep prosthetic infections in a specialist orthopaedic hospital: A 15-year prospective survey. J. Bone Jt. Surg. 2006, 88, 943-948. [CrossRef] [PubMed]

5. Jämsen, E.; Huhtala, H.; Puolakka, T.; Moilanen, T. Risk factors for infection after knee arthroplasty: A register-based analysis of 43,149 cases. J. Bone Jt. Surg. 2009, 91, 38-47. [CrossRef] [PubMed] 
6. Peersman, G.; Laskin, R.; Davis, J.; Peterson, M. Infection in total knee replacement. Clin. Orthop. Relat. Res. 2001, 392, 15-23. [CrossRef]

7. Crismani, A.G.; Bertl, M.H.; Čelar, A.G.; Bantleon, H.P.; Burstone, C.J. Miniscrews in orthodontic treatment-Review and analysis of published clinical trials. Am. J. Orthod. Dentofac. Orthop. 2010, 137, 108-113. [CrossRef]

8. Dalessandri, D.; Salgarello, S.; Dalessandri, M.; Lazzaroni, E.; Piancino, M. Determinants for success rates of temporary anchorage devices in orthodontics: A meta-analysis $(n>50)$. Eur. J. Orthod. 2014, 36, 303-313. [CrossRef]

9. Cunha, A.C.; da Veiga, A.M.A.; Masterson, D.; Mattos, C.T.; Nojima, L.I. How do geometry-related parameters influence the clinical performance of orthodontic mini-implants? A systematic review and meta-analysis. Int. J. Oral Maxillofac. Surg. 2017, 46, 1539-1551. [CrossRef]

10. Mohammadi, A.; Zarghami, A.; Sadrhaghighi, A.H. The effect of mini-implant design on peri-implantitis and pain level after insertion in orthodontic treatment: A prospective clinical study. J. Periodontol. Implant Dent. 2016, 8, 55-59.

11. Park, H.S.; Jeong, S.H.; Kwon, O.W. Factors affecting the clinical success of screw implants used as orthodontic anchorage. Am. J. Orthod. Dentofac. Orthop. 2006, 130, 18-25. [CrossRef] [PubMed]

12. Miyawaki, S.; Koyama, I.; Inoue, M.; Mishima, K.; Sugahara, T. Factors associated with the stability of titanium screws placed in the posterior region for orthodontic anchorage. Am. J. Orthod. Dentofac. Orthop. 2003, 124, 373-378. [CrossRef]

13. Coculescu, B.I. Antimicrobial resistance induced by genetic change. J. Med. Life 2009, 2, 114-123. [PubMed]

14. Balsalobre, L.C.; Dropa, M.; Matté, M.H. An overview of antimicrobial resistance and its public health significance. Braz. J. Microbiol. 2014, 45, 1-6. [CrossRef] [PubMed]

15. Zhang, F.; Shi, Z.L.; Chua, P.H.; Kang, E.T.; Neoh, K.G. Functionalization of titanium surfaces via controlled living radical polymerization: From antibacterial surface to surface for osteoblast adhesion. Ind. Eng. Chem. Res. 2007, 46, 9077-9086. [CrossRef]

16. Antoci, V.; Adams, C.S.; Parvizi, J.; Ducheyne, P.; Shapiro, I.M. Covalently attached vancomycin provides a nanoscale antibacterial surface. Clin. Orthop. Relat. Res. 2007, 461, 81-87. [CrossRef] [PubMed]

17. Radin, S.; Ducheyne, P. Controlled release of vancomycin from thin sol-gel films on titanium alloy fracture plate material. Biomaterials 2007, 28, 1721-1729. [CrossRef]

18. Goodman, S.B.; Yao, Z.; Keeney, M.; Yang, F. The future of biologic coatings for orthopaedic implants. Biomaterials 2013, 34, 3174-3183. [CrossRef]

19. Bhattacharyya, S.; Agrawal, A.; Knabe, C.; Ducheyne, P. Sol-gel silica controlled release thin films for the inhibition of methicillin-resistant Staphylococcus aureus. Biomaterials 2014, 35, 509-517. [CrossRef]

20. Ferraris, S.; Spriano, S. Antibacterial titanium surfaces for medical implants. Mater. Sci. Eng. C 2016, 61, 965-978. [CrossRef]

21. Mihailescu, I.N.; Bociaga, D.; Socol, G.; Stan, G.E.; Chifiriuc, M.C. Fabrication of antimicrobial silver-doped carbon structures by combinatorial pulsed laser deposition. Int. J. Pharm. 2016, 515, 592-606. [CrossRef] [PubMed]

22. Raucci, M.G.; Adesanya, K.; di Silvio, L.; Catauro, M.; Ambrosio, L. The biocompatibility of silver-containing $\mathrm{Na}_{2} \mathrm{O} \cdot \mathrm{CaO} \cdot 2 \mathrm{SiO}_{2}$ glass prepared by sol-gel method: In vitro studies. J. Biomed. Mater. Res. B Appl. Biomater. 2010, 92, 102-110. [CrossRef] [PubMed]

23. Stranak, V.; Wulff, H.; Ksirova, P.; Zietz, C.; Drache, S. Ionized vapor deposition of antimicrobial Ti-Cu films with controlled copper release. Thin Solid Films 2014, 550, 389-394. [CrossRef]

24. Macomber, L.; Imlay, J.A. The iron-sulfur clusters of dehydratases are primary intracellular targets of copper toxicity. Proc. Natl. Acad. Sci. USA 2009, 106, 8344-8349. [CrossRef] [PubMed]

25. Petrini, P.; Arciola, C.R.; Pezzali, I.; Bozzini, S.; Montanaro, L. Antibacterial activity of zinc modified titanium oxide surface. Int. J. Artif. Organs 2018, 29, 434-442. [CrossRef]

26. Hempel, F.; Finke, B.; Zietz, C.; Bader, R.; Weltmann, K.D. Antimicrobial surface modification of titanium substrates by means of plasma immersion ion implantation and deposition of copper. Surf. Coat. Technol. 2014, 256, 52-58. [CrossRef]

27. Hauert, R.; Gampp, R.; Müller, U.; Schroeder, A.; Blum, J. Surface analysis and bioreactions on silver-containing amorphous hydrogenated carbon films. Polym. Repr. 1997, 38, 994-995. 
28. Agarwal, A.; Weis, T.L.; Schurr, M.J.; Faith, N.G.; Czuprynski, C.J. Surfaces modified with nanometer-thick silver-impregnated polymeric films that kill bacteria but support growth of mammalian cells. Biomaterials 2010, 31, 680-690. [CrossRef]

29. Mass, A.; Bruno, A.; Bosetti, M.; Biasibetti, A.; Cannas, M. Prevention of pin track infection in external fixation with silver coated pins-Clinical and microbiological results. J. Biomed. Mater. Res. 2000, 53, 600-604. [CrossRef]

30. Shirai, T.; Tsuchiya, H.; Shimizu, T.; Ohtani, K.; Zen, Y. Prevention of pin tract infection with titanium-copper alloys. J. Biomed. Mater. Res. B Appl. Biomater. 2009, 91, 373-380. [CrossRef]

31. Cloutier, M.; Harnagea, C.; Hale, P.; Seddiki, O.; Rosei, F. Long-term stability of hydrogenated DLC coatings: Effects of aging on the structural, chemical and mechanical properties. Diam. Relat. Mater. 2014, 48, 65-72. [CrossRef]

32. Cloutier, M.; Turgeon, S.; Busby, Y.; Tatoulian, M.; Pireaux, J.J. Controlled distribution and clustering of silver in Ag-DLC nanocomposite coatings using a hybrid plasma approach. ACS Appl. Mater. Interfaces 2016, 8, 21020-21027. [CrossRef] [PubMed]

33. Rebelo, R.; Manninen, N.K.; Fialho, L.; Henriques, M.; Carvalho, S. Morphology and oxygen incorporation effect on antimicrobial activity of silver thin films. Appl. Surf. Sci. 2016, 371, 1-8. [CrossRef]

34. Serrano, C.; García-Fernández, L.; Fernández-Blázquez, J.P.; Barbeck, M.; Ghanaati, S. Nanostructured medical sutures with antibacterial properties. Biomaterials 2015, 52, 291-300. [CrossRef] [PubMed]

35. Elashnikov, R.; Lyutakov, O.; Ulbrich, P.; Svorcik, V. Light-activated polymethylmethacrylate nanofibers with antibacterial activity. Mater. Sci. Eng. C 2016, 64, 229-235. [CrossRef] [PubMed]

36. Lyutakov, O.; Goncharova, I.; Rimpelova, S.; Kolarova, K.; Svanda, J. Silver release and antimicrobial properties of PMMA films doped with silver ions, nano-particles and complexes. Mater. Sci. Eng. C 2015, 49, 534-540. [CrossRef] [PubMed]

37. Hong, K.H. Preparation and properties of electrospun poly(vinyl alcohol)/silver fiber web as wound dressings. Polym. Eng. Sci. 2007, 47, 43-49. [CrossRef]

38. Mahltig, B.; Haufe, H.; Böttcher, H. Functionalisation of textiles by inorganic sol-gel coatings. J. Mater. Chem. 2005, 15, 4385-4398. [CrossRef]

39. Rujitanaroj, P.O.; Pimpha, N.; Supaphol, P. Wound-dressing materials with antibacterial activity from electrospun gelatin fiber mats containing silver nanoparticles. Polymer 2008, 49, 4723-4732. [CrossRef]

40. Körner, E.; Aguirre, M.H.; Fortunato, G.; Ritter, A.; Rühe, J. Formation and distribution of silver nanoparticles in a functional plasma polymer matrix and related $\mathrm{Ag}^{+}$release properties. Plasma Process. Polym. 2010, 7 , 619-625. [CrossRef]

41. Vasilev, K.; Sah, V.; Anselme, K.; Ndi, C.; Mateescu, M. Tunable antibacterial coatings that support mammalian cell growth. Nano Lett. 2010, 10, 202-207. [CrossRef] [PubMed]

42. Jelínek, M.; Zemek, J.; Remsa, J.; Mikšovský, J.; Kocourek, T. Hybrid laser technology and doped biomaterials. Appl. Surf. Sci. 2017, 417, 73-83. [CrossRef]

43. Ming, M.Y.; Jiang, X.; Piliptsou, D.G.; Zhuang, Y.; Rogachev, A.V. Chromium-modified a-C films with advanced structural, mechanical and corrosive-resistant characteristics. Appl. Surf. Sci. 2016, 379, 424-432. [CrossRef]

44. Lee, N.R.; Jun, Y.S.; Moon, K.I.; Lee, C.S. Ti-doped hydrogenated diamond like carbon coating deposited by hybrid physical vapor deposition and plasma enhanced chemical vapor deposition. Jpn. J. Appl. Phys. 2017, 56, 35506. [CrossRef]

45. Xuemin, W.; Weidong, W.; Shengyin, L.; Li, B.; Linhong, C. Properties of W incorporated diamond-like carbon films prepared by pulsed-laser deposition. J. Alloy. Compd. 2009, 479, 741-745. [CrossRef]

46. Müller, I.C.; Sharp, J.; Rainforth, W.M.; Hovsepian, P.; Ehiasarian, A. Tribological response and characterization of Mo-W doped DLC coating. Wear 2017, 376-377, 1622-1629.

47. Marciano, F.R.; Bonetti, L.F.; Santos, L.V.; Da-Silva, N.S.; Corat, E.J. Antibacterial activity of DLC and Ag-DLC films produced by PECVD technique. Diam. Relat. Mater. 2009, 18, 1010-1014. [CrossRef]

48. Wang, C.; Yu, X.; Hua, M. Microstructure and mechanical properties of Ag-containing diamond-like carbon films in mid-frequency dual-magnetron sputtering. Appl. Surf. Sci. 2009, 256, 1431-1435. [CrossRef]

49. Sun, L.; Guo, P.; Ke, P.; Li, X.; Wang, A. Synergistic effect of $\mathrm{Cu} / \mathrm{Cr}$ co-doping on the wettability and mechanical properties of diamond-like carbon films. Diam. Relat. Mater. 2016, 68, 1-9. [CrossRef] 
50. Pang, X.; Shi, L.; Wang, P.; Xia, Y.; Liu, W. Effects of Al incorporation on the mechanical and tribological properties of Ti-doped a-C:H films deposited by magnetron sputtering. Curr. Appl. Phys. 2011, 11, 771-775. [CrossRef]

51. Lan, W.C.; Ou, S.F.; Lin, M.H.; Ou, K.L.; Tsai, M.Y. Development of silver-containing diamond-like carbon for biomedical applications. Part I: Microstructure characteristics, mechanical properties and antibacterial mechanisms. Ceram. Int. 2013, 39, 4099-4104. [CrossRef]

52. Bonilla-Gameros, L.; Cloutier, M.; Montaño-Machado, V.; Chevallier, P.; Mantovani, D. Controlling silver ion release from Ag-based nanocoatings by plasma surface engineering. MSF 2018, 941, 1625-1631. [CrossRef]

53. Gorzelanny, C.; Kmeth, R.; Obermeier, A.; Bauer, A.T.; Halter, N. Silver nanoparticle-enriched diamond-like carbon implant modification as a mammalian cell compatible surface with antimicrobial properties. Sci. Rep. 2016, 6, 22849. [CrossRef] [PubMed]

54. Baba, K.; Hatada, R.; Flege, S.; Ensinger, W.; Shibata, Y. Preparation and antibacterial properties of Ag-containing diamond-like carbon films prepared by a combination of magnetron sputtering and plasma source ion implantation. Vacuum 2013, 89, 179-184. [CrossRef]

55. Chan, Y.H.; Huang, C.F.; Ou, K.L.; Peng, P.W. Mechanical properties and antibacterial activity of copper doped diamond-like carbon films. Surf. Coat. Technol. 2011, 206, 1037-1040. [CrossRef]

56. Endrino, J.L.; Anders, A.; Albella, J.M.; Horton, J.A.; Horton, T.H. Antibacterial efficacy of advanced silver-amorphous carbon coatings deposited using the pulsed dual cathodic arc technique. J. Phys. Conf. Ser. 2010, 252, 12012. [CrossRef]

57. Chang, Y.Y.; Wang, D.Y.; Wu, W. Catalysis effect of metal doping on wear properties of diamond-like carbon films deposited by a cathodic-arc activated deposition process. Thin Solid Films 2002, 420-421, 241-247. [CrossRef]

58. Zou, C.W.; Wang, H.J.; Feng, L.; Xue, S.W. Effects of Cr concentrations on the microstructure, hardness, and temperature-dependent tribological properties of Cr-DLC coatings. Appl. Surf. Sci. 2013, 286, 137-141. [CrossRef]

59. Polak, M.; Ohl, A.; Quaas, M.; Lukowski, G.; Lüthen, F. Oxygen and water plasma-immersion ion implantation of copper into titanium for antibacterial surfaces of medical implants. Adv. Eng. Mater. 2010, 12, B511-B518. [CrossRef]

60. Chu, P.K. Applications of plasma-based technology to microelectronics and biomedical engineering. Surf. Coat. Technol. 2009, 203, 2793-2798. [CrossRef]

61. Schröder, K.; Finke, B.; Polak, M.; Lüthen, F.; Nebe, B.; Rychly, J.; Bader, R.; Lukowski, G.; Walschus, U.; Schlosser, M.; et al. Gas-discharge plasma-assisted functionalization of titanium implant surfaces. MSF 2010, 638-642, 700-705.

62. Jelinek, M.; Zemek, J.; Vandrovcova, M.; Bacakova, L.; Kocourek, T. Bonding and bio-properties of hybrid laser/magnetron Cr-enriched DLC layers. Mater. Sci. Eng. C 2016, 58, 1217-1224. [CrossRef] [PubMed]

63. Foong, Y.M.; Koh, A.T.T.; Lim, S.R.; Chua, D.H.C.; Ng, H.Y. Properties of laser fabricated nanostructured $\mathrm{Cu}$ /diamond-like carbon composite. J. Mater. Res. 2011, 26, 2761-2771. [CrossRef]

64. Zhang, H.S.; Endrino, J.L.; Anders, A. Comparative surface and nano-tribological characteristics of nanocomposite diamond-like carbon thin films doped by silver. Appl. Surf. Sci. 2008, 255, 2551-2556. [CrossRef]

65. Bociaga, D.; Jakubowski, W.; Komorowski, P.; Sobczyk-Guzenda, A.; Jędrzejczak, A. Surface characterization and biological evaluation of silver-incorporated DLC coatings fabricated by hybrid RF PACVD/MS method. Mater. Sci. Eng. C 2016, 63, 462-474. [CrossRef] [PubMed]

66. Harrasser, N.; Jüssen, S.; Obermeir, A.; Kmeth, R.; Stritzker, B. Antibacterial potency of different deposition methods of silver and copper containing diamond-like carbon coated polyethylene. Biomater. Res. 2016, 20, 17. [CrossRef] [PubMed]

67. Burghardt, I.; Lüthen, F.; Prinz, C.; Kreikemeyer, B.; Zietz, C. A dual function of copper in designing regenerative implants. Biomaterials 2015, 44, 36-44. [CrossRef]

68. Zietz, C.; Fritsche, A.; Finke, B.; Stranak, V.; Haenle, M. Analysis of the release characteristics of Cu-treated antimicrobial implant surfaces using atomic absorption spectrometry. Bioinorg. Chem. Appl. 2012, 2012, 850390. [CrossRef] 
69. Finke, B.; Polak, M.; Hempel, F.; Rebl, H.; Zietz, C. Antimicrobial potential of copper-containing titanium surfaces generated by ion implantation and dual high power impulse magnetron sputtering. Adv. Eng. Mater. 2012, 14, B224-B230. [CrossRef]

70. Patenge, N.; Arndt, K.; Eggert, T.; Zietz, C.; Kreikemeyer, B. Evaluation of antimicrobial effects of novel implant materials by testing the prevention of biofilm formation using a simple small scale medium-throughput growth inhibition assay. Biofouling 2012, 28, 267-277. [CrossRef]

71. Stranak, V.; Wulff, H.; Rebl, H.; Zietz, C.; Arndt, K. Deposition of thin titanium-copper films with antimicrobial effect by advanced magnetron sputtering methods. Mater. Sci. Eng. C 2011, 31, 1512-1519. [CrossRef]

72. Amberg, M.; Vandenbossche, M.; Hegemann, D. Controlled Ag release from electrically conductive coating systems. Surf. Coat. Technol. 2018, 336, 29-33. [CrossRef]

73. Nißen, S.; Heeg, J.; Wienecke, M.; Behrend, D.; Warkentin, M. Enhancing adhesion strength of a-C:H:Cu composite coatings on Ti6Al4V by graded copper deposition in a rf-PVD/PECVD hybrid process. Surf. Coat. Technol. 2018, 350, 659-671. [CrossRef]

74. Nelis, T.; Payling, R. Glow discharge optical emission spectroscopy: A practical guide. R. Soc. Chem. 2007.

75. March, G.; Nguyen, T.D.; Piro, B. Modified electrodes used for electrochemical detection of metal ions in environmental analysis. Biosensors 2015, 5, 241-275. [CrossRef] [PubMed]

76. Guo, P.; Sun, L.; Li, X.; Xu, S.; Ke, P. Structural properties and surface wettability of Cu-containing diamond-like carbon films prepared by a hybrid linear ion beam deposition technique. Thin Solid Films 2015, 584, 289-293. [CrossRef]

77. Sun, L.; Guo, P.; Li, X.; Wang, A. Comparative study on structure and wetting properties of diamond-like carbon films by W and Cu doping. Diam. Relat. Mater. 2017, 73, 278-284. [CrossRef]

78. Ma, W.J.; Ruys, A.J.; Mason, R.S.; Martin, P.J.; Bendavid, A. DLC coatings: Effects of physical and chemical properties on biological response. Biomaterials 2007, 28, 1620-1628. [CrossRef] [PubMed]

79. Salgueiredo, E.; Vila, M.; Silva, M.A.; Lopes, M.A.; Santos, J.D. Biocompatibility evaluation of DLC-coated $\mathrm{Si}_{3} \mathrm{~N}_{4}$ substrates for biomedical applications. Diam. Relat. Mater. 2008, 17, 878-881. [CrossRef]

80. Kwok, S.C.H.; Wang, J.; Chu, P.K. Surface energy, wettability, and blood compatibility phosphorus doped diamond-like carbon films. Diam. Relat. Mater. 2005, 14, 78-85. [CrossRef]

81. Yang, P.; Huang, N.; Leng, Y.X.; Yao, Z.Q.; Zhou, H.F. Wettability and biocompatibility of nitrogen-doped hydrogenated amorphous carbon films: Effect of nitrogen. Nucl. Instrum. Methods Phys. Res. Sect. B 2006, 242, 22-25. [CrossRef]

82. Zhao, Q.; Liu, Y.; Wang, C.; Wang, S. Bacterial adhesion on silicon-doped diamond-like carbon films. Diam. Relat. Mater. 2007, 16, 1682-1687. [CrossRef]

83. Logothetidis, S. Haemocompatibility of carbon based thin films. Diam. Relat. Mater. 2007, 16, $1847-1857$. [CrossRef]

84. Jelínek, M.; Smetana, K.; Kocourek, T.; Dvořánková, B.; Zemek, J.; Remsa, J.; Luxbacher, T. Biocompatibility and $\mathrm{sp}^{3} / \mathrm{sp}^{2}$ ratio of laser created DLC films. Mater. Sci. Eng. B 2010, 169, 89-93.

85. Wei, C.; Pan, W.J.; Hung, M.S. The effects of substrate roughness and associated surface properties on the biocompatibility of diamond-like carbon films. Surf. Coat. Technol. 2013, 224, 8-17. [CrossRef]

86. Tsai, M.Y.; Huang, M.S.; Chen, L.K.; Shen, Y.D.; Lin, M.H. Surface properties of copper-incorporated diamond-like carbon films deposited by hybrid magnetron sputtering. Ceram. Int. 2013, 39, 8335-8340. [CrossRef]

87. Robertson, J. Diamond-like amorphous carbon. Mater. Sci. Eng. 2002, 37, 129-281. [CrossRef]

(C) 2019 by the authors. Licensee MDPI, Basel, Switzerland. This article is an open access article distributed under the terms and conditions of the Creative Commons Attribution (CC BY) license (http://creativecommons.org/licenses/by/4.0/). 